\title{
A review of the impact of climate change on future nitrate concentrations in groundwater of the UK
}

\author{
M. E. Stuart", D. C. Gooddy, J. P. Bloomfield, A. T. Williams \\ British Geological Survey, Maclean Building, Wallingford, Oxon, OX10 8BB, UK \\ *Corresponding author: tel: +44 (0) 1491 692298; fax +44 (0) 1491692345. \\ E-mail address: mest@,bgs.ac.uk (M. E. Stuart)
}

\begin{abstract}
This paper reviews the potential impacts of climate change on nitrate concentrations in groundwater of the UK using a Source-Pathway-Receptor framework. Changes in temperature, precipitation quantity and distribution, and atmospheric carbon dioxide concentrations will affect the agricultural nitrate source term through changes in both soil processes and agricultural productivity. Non-agricultural source terms, such as urban areas and atmospheric deposition, are also expected to be affected. The implications for the rate of nitrate leaching to groundwater as a result of these changes are not yet fully understood but predictions suggest that leaching rate may increase under future climate scenarios. Climate change will affect the hydrological cycle with changes to recharge, groundwater levels and resources and flow processes. These changes will impact on concentrations of nitrate in abstracted water and other receptors, such as surface water and groundwater-fed wetlands. The implications for nitrate leaching to groundwater as a result of climate changes are not yet well enough understood to be able to make useful predictions without more site-specific data. The few studies which address the whole cycle show likely changes in nitrate leaching ranging from limited increases to a possible doubling of aquifer concentrations by 2100 . These changes may be masked by nitrate reductions from improved agricultural practices, but a range of adaption measures need to be identified. Future impact may also be driven by economic responses to climate change.
\end{abstract}

Keywords: Nitrate; Climate Change; Groundwater; Source-Pathway-Receptor; Driver/Pressure 


\section{Introduction}

Understanding the impact of climate change on the hydrological cycle, particularly the impacts on water quality, is essential for ensuring the sustainability of future water resources. Such impacts have been the focus of numerous site- and processes- specific studies over the last couple of decades. More recently, due to the complexity of the potential environmental responses to change, a number of studies or overviews have attempted to integrate findings from site and case studies. For example, the potential impacts of climate change on agriculture have been reviewed by Downing et al. (2000), on UK surface water quality by Whitehead et al. (2009), and the fate and transport of pesticides in ground and surface water by Bloomfield et al. (2006). Taking the UK as a case study, this paper provides an overview of the potential impacts of climate change on nitrate concentrations in groundwater using a Source-Pathway-Receptor framework.

In the UK, nitrate is almost ubiquitous in groundwater, often at elevated concentrations and exceeding drinking water standards (Rivett et al., 2007). It is the most widespread groundwater quality problem facing the UK water industry and environmental regulators, as it is the single biggest cause of groundwater body status failure under the WFD (UKWIR, 2004). Nitrate concentrations are predicted to continue to rise in many places over the next decade (Stuart et al., 2007). If present trends continue, many groundwater sources could exceed the drinking water standard by 2015, as indicated by trend analysis reported in River Basin Management Plans. Significant seasonality also gives potentially problematic concentrations during the winter months. Holman and Loveland (2001) set out a crosssectorial regional assessment of climate change (RegIS) which included water resources. They used the Driver-Pressure-State-Impact-Response approach to link climate change, agricultural sector, water resources, and receptors such as water quality, biodiversity and societal response. We have used a similar approach in this study.

In order to understand the nature of climate change impact on groundwater nitrate concentrations, three important questions need to be addressed:

- What are the likely changes to agricultural practices and how may these affect nitrate leaching from the soil zone?

- What are the likely changes to groundwater recharge mechanisms and groundwater levels? 
- What are the likely changes to nitrate concentrations in groundwater and the consequent impact on groundwater receptors?

We address these questions by applying a Source-Pathway-Receptor model to the nitrogen (N) cycle. A simplified version of the $\mathrm{N}$ cycle is shown in Fig. 1. This includes direct run off from the soil to surface water, bypassing groundwater. This process is not covered in depth in this review. The Source-Pathway-Receptor model provides a convenient conceptual framework to allow the various factors to be considered individually. It is accepted that such a simplification excludes the interaction of this cycle with other element cycles and with the water cycle (Cresser et al., 2008). The Source-Pathway-Receptor model also includes a Driver/Pressure term to express climate change, where for this study we use climate change scenarios from the UK Climate Impacts Programme (UKCIP).

Figure 1

The study draws on extensive literature mainly from the UK and so presents a UK-based perspective, although literature for other temperate climates is included to augment that from the UK and to demonstrate that the proposed framework and general conclusions have a wider applicability.

The principal $\mathrm{N}$ input to $\mathrm{UK}$ groundwater is derived from manures, fertilisers, sewage sludges and crop residues in agricultural areas (DEFRA, 2006). There are also smaller inputs from urban point sources and aerial deposition (Wakida and Lerner, 2005). $\mathrm{N}$ fertiliser can be applied as urea or ammonia, as well as nitrate, but the non-nitrate forms are generally converted rapidly to nitrate in the soils of the UK (MAFF, 1999). A small percentage of applied $\mathrm{N}$ is lost to the atmosphere as $\mathrm{NH}_{3}, \mathrm{NO}$ or $\mathrm{N}_{2} \mathrm{O}$ (Destouni and Darracq, 2009; Skiba et al., 1997; Sommer and Hutchings, 1995). A proportion of soil $\mathrm{N}$ is leached as nitrate from the base of the soil. This is either stored in, or transmitted through, the unsaturated zone to groundwater.

Scenarios of climate change for the UK have been produced by UKCIP in 1998 (Hulme and Jenkins, 1998) and 2002 (Hulme et al., 2002), and recent climate conditions have fallen broadly within the range of projections. The most recent predictions for the UK, UKCP09, now include feedback within the atmospheric carbon cycle and uncertainties in the feedback from the land carbon cycle (Murphy et al., 2009). These climate change scenarios are used as a reference throughout the paper and are summarised in Table 1. The emissions scenarios used in UKCP09 reflect a range of social and economic changes including population, 
economic growth, technological developments, energy usage and type, and land use. It is assumed that land use change will slow down but there will be continued agricultural intensification due to rising global demand for food.

The projected changes show a wide range of uncertainty with the temperature differential between southern England and northern areas perhaps greater than at present, but with less predictable changes in distribution and intensity of rainfall.

Characterising uncertainty in climate impact modelling studies is currently the focus of extensive work. For example, Prudhomme and Davies (2009) investigated three sources of uncertainty surrounding climate change impact studies on river flows in the UK: uncertainty in General Circulation Models (GCMs), in downscaling techniques and in hydrological modelling and showed that GCM uncertainty is generally larger than downscaling uncertainty, and both are consistently greater than uncertainty from hydrological modelling or natural variability. However, no downscaling technique was found to be significantly better or to have a systematic bias smaller than the others. Jackson et al. (2011) applied a suite of outputs from thirteen different GCM models to a regional distributed groundwater model of the Chalk aquifer of Berkshire, UK to investigate uncertainty in the driving GCMs on groundwater. They found that although an ensemble average suggests there will be about a $5 \%$ reduction in annual potential groundwater recharge across the study area, this was not statistically significant at the $95 \%$ confidence level and more importantly observed that the spread of results for simulated changes in annual potential groundwater recharge range from a $26 \%$ decrease to a $31 \%$ increase by the 2080 s, with ten GCMs predicting a decrease and three an increase in potential recharge.

An important additional source of uncertainty in the impacts of climate change is the method by which the climate data are downscaled. Many of the UK studies have used change factor / delta methods, which will produce very different understanding of impacts to that which will be gained by the probabilistic UKCP09 scenarios. There are as yet few published studies on this, although Fowler et al (2007) look at the issue in the broader context of hydrological modelling, and Holman et al (2009) compares methods for potential recharge.

Position of Table 1 


\section{Climate change and the nitrogen source term}

\subsection{Leaching from agricultural land}

Nitrate in UK groundwater is derived primarily from agricultural sources (Wilson et al., 1994). Predictions using the NEAP-N model, which estimates current losses from the base of the soil zone from agricultural land, show that concentrations range up to $180 \mathrm{mg} \mathrm{L}^{-1} \mathrm{NO}_{3}$ (Silgram et al., 2001). Concentrations higher than this have been recorded within potential recharge leaving the soil zone (e.g. Rozemeijer et al. 2009). Whilst it is clear that climate change will have a significant impact on crop yields and geographical distribution, it is difficult to predict what these will be and relate these directly to changes in nitrate availability in the soil. For leaching processes the impacts are clearer with most changes leading to increased nitrate leaching.

Currently the UK climate is well-suited to temperate zone crops with good adaptation to cooler temperatures: yields of wheat, barley, oats and sugar beet are amongst the highest in the world (MAFF, 2000). Most studies of climate change impacts on agriculture have analysed the effects of long-term climatic changes on crop production, but the impacts of increasing climatic variability should also be included (De Jong et al., 2008). The impact of changes to the flux of $\mathrm{N}$ leaching from the base of the soil must also be included. Fig. 2 summarises the ways in which increased greenhouse gases could have an impact on agricultural nitrate leaching. The main factors considered in this review are changes in agricultural land use and soil mineralisation; these are discussed below.

Position of Figure 2

\subsubsection{Changes in crop yield and distribution}

Crop yields are affected by many factors associated with climate change including temperature, rainfall, atmospheric $\mathrm{CO}_{2}$ concentration, extreme weather events and climate variability (MAFF, 2000; $\mathrm{RR}, 2009$ ). Of these, increased $\mathrm{CO}_{2}$ is mostly beneficial, although it can result in the requirement for additional fertiliser applications, whereas others such as temperature and rainfall can be both beneficial and detrimental. For northern Europe climate change is projected to bring mixed effects on agricultural productivity (IPCC, 2007). Cline (2007) quotes a range of scenarios giving changes varying from between $-4 \%$ and $11 \%$ to between $10 \%$ and $28 \%$ increase in agricultural capacity for the UK by 2080 . A summary of the possible impacts on temperate crop yields and changes in distribution of cropped areas in shown in Table 2. 


\section{Position of Table 2}

Overall, crop productivity is predicted to increase slightly at mid to high latitudes for local mean total temperature increases of $1-3{ }^{\circ} \mathrm{C}$ depending on the crop type then decrease beyond that in some regions (IPCC, 2007). Higher temperatures during the growing season speed annual crops through their development and a lower mass may be produced in all but very northerly areas, such as Canada and Russia (Parry et al., 1999). The other main cause of falling yields is the projected decrease in water availability due to increase in evapotranspiration, enhanced losses of soil moisture and a projected decrease in precipitation. Poor vernalisation, an insufficient period of low winter temperatures to initiate or accelerate the flowering process, can also be important (Parry et al., 1999). In the short term, climate warming will allow earlier planting or sowing combined with a short-season cultivar to minimise the impact of heat and water stress.

Most cereals and fruit are determinate plants, where a flower or bud terminates the growing tip, flowering occurs all at once over a short period and there is a rapid switch from vegetative growth to seed formation and filling. These crops are therefore vulnerable to transient stresses. In contrast, indeterminate crops, such as sugar beet and maize, maintain vegetative apices and flower from axillary buds over longer periods. These crops are less efficient yield producers under favourable conditions but provide yield stability. We could therefore anticipate a long-term switch to indeterminate crop types in the warmer, drier parts of the UK based on climatic sensitivity although this may be offset by the continued high demand for cereals. Parry et al. (1999) used a percentage increase in global cereal prices of between 20 and $40 \%$ by 1980 depending on the climate scenario.

The predicted effect of increased atmospheric $\mathrm{CO}_{2}$ concentrations is to increase the rate of photosynthesis and growth (carbon fertilisation) and to reduce the amount of water required for unit biomass (MAFF, 2000). Gauging the influence of higher atmospheric concentrations of $\mathrm{CO}_{2}$ on crop yields (carbon fertilisation) is therefore crucial to estimates of agricultural impact (Cline, 2007; Olesen and Bindi, 2002). Crops are divided into two types, $\mathrm{C}_{3}$ and $\mathrm{C}_{4}$, depending on the mechanism of photosynthesis. $\mathrm{C}_{3}$ crops benefit substantially more from carbon fertilisation. Crops belonging to the $\mathrm{C}_{3}$ group include low temperature crops such as wheat, potatoes, barley, oats, higher temperature crops such as soybeans, rice, cassava, as well as legumes and most trees. The $\mathrm{C}_{4}$ group includes maize, millet, sorghum and sugarcane. 
Work on the original projections for carbon fertilisation using studies from enclosures, such as greenhouses, suggested rising yields particularly for $\mathrm{C}_{3}$ crops of up to $30 \%$ (summarised in Cline (2007)). It was assumed that these increases could offset declines in yield due to other climate change factors. More recent work using the free air concentration enrichment method (FACE) suggests that the impact is likely to be perhaps only $50 \%$ of the original predictions (Long et al., 2006). Lesser increased yields may also be seen for $\mathrm{C}_{4}$ crops (Torbert et al., 2004).

It is well established that elevated $\mathrm{CO}_{2}$ reduces plant stomatal conductance, transpiration and dark respiration, improving water use efficiency (Drake et al., 1997). The combined effect of these processes is to increase usage efficiency of radiation, $\mathrm{N}$ and water. Morison and Gifford (1983) showed that the sensitivity of stomatal conductance to increases in $\mathrm{CO}_{2}$ for $\mathrm{C}_{3}$ and $\mathrm{C}_{4}$ grasses was similar. Transpiration efficiency was larger in the $\mathrm{C}_{4}$ species but the relative increase was larger in C3. The observed increase in global river runoff through the 20th century has been related to the reduction of plant uptake of water due to $\mathrm{CO}_{2}$ induced stomatal closure (Betts et al., 2007; Gedney et al., 2006). Sinclair (1992) showed that the availability of mineral nutrition limited the potential effects of $\mathrm{CO}_{2}$ uptake. Grasslands may be amongst the earliest systems to be affected (Ball and Pocock, 1997).

In an integrated assessment (ReGIS), using East Anglia and the northwest of England as case studies, Holman et al. (2005a) record the scope provided by climate change to extend the range of currently grown crops, such as sugar beet and potatoes, to introduce new crops: sunflowers, grain and forage maize and to alter current rotations. There may also be a move from grassland to arable farming, due to economic pressures and an increase in arable area in upland catchments. Tuck et al. (2006) assess the potential distribution of a wide range of biofuel crops under climate changes in different latitudes and longitudes of Europe. There is the potential for a substantial increase in extent for olives, sorghum and possibly peanuts in England and field mustard, hemp and reed canary grass in Scotland. There are many other factors which influence agricultural practice, including regulations and demographic pressures.

\subsubsection{Impact on nitrogen leaching from agricultural land}

Most nitrate leached from arable soils originates from inorganic $\mathrm{N}$ present in the soil pool in late summer, autumn or early winter, when plant demand is low. This residual is liable to leaching in late autumn or early winter (White et al., 1983). Losses from crops are therefore a 
function of the interactions between over-winter rainfall, soil type and water holding capacity, cropping, and the rate/timing of fertiliser/manure applications. Goulding (2000) and Di and Cameron (2002) suggest an increasing potential for leaching flux in the order forest $<$ cut grassland $<$ grazed pastures $<$ arable cropping $<$ ploughing of pasture $<$ market gardens . Nitrate leaching beneath individual crops, measured by means of porous pot suction lysimeters or conventional lysimeters, appears to be very variable on the field scale (Cuny et al., 1998; Goulding et al., 2000; Owens et al., 2000; Wu et al., 1995). Leaching can also be estimated from the $\mathrm{N}$ balance by measuring the other elements of the $\mathrm{N}$ cycle (Lord et al., 2002; Salo and Turtola, 2006; Sieling and Kage, 2006). Many of these studies report leached $\mathrm{N}$ as a concentration rather than a flux and make these studies difficult to compare.

Estimates identify outdoor vegetables, potatoes and oil seed rape as giving the greatest losses under current agricultural practices (Table 3). This data has some limitations as it is derived mainly from point source measurements and also does not account for cumulative effects from previous crops. Data for possible new crops such as sunflowers, soybeans, various types of maize, and sorghum are more-readily available from warmer climatic areas, such as Spain, USA and China, and may not be comparable to the UK (Owens et al., 2000; Scott Angle, 1990; Zhao et al., 2006; Zhu and Fox, 2003).

Position of Table 3

Future nitrate leaching will also be affected by continued changes to agricultural practices designed to reduce nitrate leaching, such as catchcrops and rotations (Beaudoin et al., 2005; DEFRA, 2009; Francis et al., 1998; Herrera and Liedgens, 2009; Justes et al., 1999; Thomsen, 2005). The $\mathrm{N}$ balance can be poorly correlated to the mass of leached nitrate in the short term but may be a good longer term indicator (Sieling and Kage, 2006). The indirect effects of changing land use and agricultural systems can have significant effects on soils (MAFF, 2000). Climate change will also modify key soil processes that underpin crop growth.

Soil mineralisation depends on the nature and abundance of the organic matter and on temperature, humidity, $\mathrm{pH}$ and faunal activity. It is widely believed that increases in ambient temperature will decrease the organic matter content of soils (Leirós et al., 1999) and this in turn can affect hydraulic properties (Bowman et al., 2000).

Net soil mineralisation of $\mathrm{N}$ is a complex process being the difference between gross mineralisation and immobilisation. The extent of mineralisation of $\mathrm{N}$ in soils increases 
linearly with soil organic matter content and with temperature (Leirós et al., 1999), leading to the build up of inorganic $\mathrm{N}$ in the soil and an increased risk of leaching (Olesen and Bindi, 2002). Soil moisture appears to be the primary variable affecting soil enzyme activity (Sardans et al., 2008). N mineralisation and nitrification are related to temperature and indirectly to rainfall (Emmett et al., 2004). The overall effects depend on how changes affect soil moisture during the summer season (Leirós et al., 1999), on the countering effects of growth enhancement from increased carbon inputs and increased nitrate uptake by vegetation (Ineson et al., 1998a; Ineson et al., 1998b).

Generally, microbial activity is lowest when the soil is either dry or saturated. Borken and Matzner (2009) reviewed the effects of wetting and drying cycles on mineralisation and concluded that increasing summer droughts will reduce mineralisation and $\mathrm{N}$ and $\mathrm{C}$ fluxes whereas increasing summer precipitation could enhance losses. They suggested that the pulse in net $\mathrm{N}$ (and C) mineralisation commonly observed following wetting of dry soil is short-lived and that this additional mineralisation during wetting may be derived from accumulated microbial and plant necromass, lysis of live microbial cells, release of solutes and exposure of previously protected organic matter.

However, soil mineralisation appears to be enhanced under climate change scenarios. To simulate increasing temperature Rustad et al. (2001) reviewed data from a number of studies using artificial warming such as undersoil heating and greenhouses. For 2-9 years of warming in the range $0.3-6{ }^{\circ} \mathrm{C}$, net $\mathrm{N}$ mineralisation rate increased by $46 \%$ and plant productivity by 19\%. Ducharne et al. (2007) modelled a number of climate change scenarios which indicated an increase of net $\mathrm{N}$ mineralisation rate of between 8 and $25 \%$ on a reference level of $94 \mathrm{~kg} \mathrm{~N}$ $\mathrm{ha}^{-1} \mathrm{yr}^{-1}$. The impact of increased temperature ( 8 to $26 \%$ ) was smaller than that reported by Rustad et al. (2001) but outweighed the reduction of mineralisation due to reduced soil water content.

Nutrient fluxes tend to be greatest under storm events, both to overland flow and to delivery of deeper soil water to drainage (Petry et al., 2002). An important control on $\mathrm{N}$ leaching to groundwater is the proportioning between run-off and infiltration. Increased rainfall intensity and changes to soil hydraulic properties will lead to a change in partitioning between run off and recharge. $\mathrm{N}$ leached directly to surface water will be removed via rivers to the sea. Soil parameters controlling the water balance, such as soil texture, organic content, hydraulic conductivity, wetting front pressure, field capacity residual water content and porosity, as well as ion exchange capacity, are key to the prediction of nitrate leaching (Vachaud and 
Chen, 2002). Shallow groundwater often shows large temporal and spatial variations in nitrate concentration. Rozemeijer et al. (2009) found weather-induced fluctuations of between $55 \%$ and $153 \%$ of average nitrate concentrations in a test farm in the Netherlands.

Callesen et al. (2007) showed that freezing and thawing of soils may alter the $\mathrm{N}$ turnover, with large losses following periods of frost due to increased ammonification and mineralisation. Matzner and Borken (2008) reviewed the mechanisms causing the post-frost pulse and suggested that nitrate losses are more likely caused by reduced root uptake rather than by increased $\mathrm{N}$ net mineralisation. Elevated nitrate losses from soils under alpine and/or arctic and forest vegetation occurred only in the year following exceptional soil frost, with greatest reported losses of a flux of about $13 \mathrm{~kg} \mathrm{~N} \mathrm{ha}^{-1} \mathrm{yr}^{-1}$. The pool of $\mathrm{N}$ susceptible to freeze-thaw events is rather limited, as indicated by decreasing losses with short-term repeated events. Thus, freeze-thaw events might induce solute losses of $\mathrm{N}$ from soils that are relevant at the annual time scale. The recent periods of below average winter temperatures in the UK suggest that this process could be relevant to large areas of the UK.

There have been a number of attempts to model the impact of climate change on $\mathrm{N}$ leaching with variable results. Olesen et al. (2007) modelled the impact of yields of winter wheat and nitrate leaching under a range of climate change scenarios. They projected that yields of $10 \mathrm{t}$ $\mathrm{ha}^{-1}$ would extend further north in the UK for the period 2071 to 2100 . However, nitrate leaching flux showed a patchy increase over the same period, although this is not quantified. Eckersten et al. (2001) modelled the possible consequences of climate change on the $\mathrm{N}$ budget of winter wheat in Southern Sweden. The effects of both elevated atmospheric $\mathrm{CO}_{2}$ and changed climate were simulated using two linked process-oriented models (SOIL/SOILN). For the year 2050 winter wheat production was predicted to increase by 10$20 \%$ compared with the present value. Precipitation and drainage was predicted to increase which resulted in an increased $\mathrm{N}$ leaching flux of $17 \%$ (from 58 to $68 \mathrm{~kg} \mathrm{ha}^{-1} \mathrm{yr}^{1}$ ). However, Ulen and Johansson (2009) showed that modelled $\mathrm{N}$ leaching flux from an arable field in Sweden using tile drain and piezometer data has increased by only $0.06 \mathrm{~kg} \mathrm{ha}^{-1} \mathrm{yr}^{-1}$ in the period 1993 to 2005 due to an increased temperature of $2^{\circ} \mathrm{C}$ during the growing season (April to September) and an increase in precipitation ( $+16 \mathrm{~mm}$ mainly in June).

The projected decrease in summer recharge and increased frequency of droughts will lead to an increased requirement for agricultural irrigation (Henriques et al., 2008). This is most likely in the drier areas of the UK, such as East Anglia. For surface water, Weatherhead and 
Howden (2009) show that future water resource constraints will limit opportunities to use irrigation, particularly in the southeast of England.

\subsection{Leaching from forests and upland areas}

Climate change may also impact on leaching from forests. Both increased temperature and $\mathrm{CO}_{2}$ concentration produce primary productivity if $\mathrm{N}$ is in sufficient supply and increase in $\mathrm{N}$ leaching although boreal ecosystems are typically $\mathrm{N}$ limited. Nadelhoffer et al. (1984) showed that mineralisation of organic matter in forests varied seasonally more than nitrification. A higher soil temperature should increase mineralisation of organic matter releasing $\mathrm{N}$ that can go to plant growth but also to run off and leaching to groundwater. showed that In a study aimed primarily at estimating $\mathrm{CO}_{2}$ sequestration Wright et al. (1998) attributed an increase in $\mathrm{N}$ flux in runoff of 5 to12 $\mathrm{mmol} \mathrm{m}^{-2} \mathrm{yr}^{-1}\left(0.7\right.$ to $\left.1.7 \mathrm{~kg} \mathrm{ha}^{-1} \mathrm{yr}^{-1}\right)$ to a $5 \%$ increase in rate of decomposition of old organic matter in response to higher temperatures. Mitchell et al. (1996) found high concentrations and high drainage water losses followed an anomalous cold period for all four sites. After high nitrate losses during the snowmelt, nitrate concentrations and fluxes decreased suggesting that climatic variation can have a major effect on nitrogen flux and cycling and may influence temporal patterns of nitrate loss in a region. Aber et al. (2002) looked at a number of disturbances on $\mathrm{N}$ leaching from a forested catchment. Relevant here are that drought events led to low $\mathrm{N}$ losses and $\mathrm{CO}_{2}$ enrichment was predicted to lead to a decreased flux of leached $\mathrm{N}$.

Many upland areas in the UK are underlain by poorly permeable strata with little utilisable groundwater. Using surface water nitrate concentrations as an analogue, these are often related to total $\mathrm{N}$ deposition since other inputs are often low (Allott et al., 1995). Monteith et al. (2000) showed that patterns of variation in nitrate concentration, observed in upland lakes and streams over the last decade, show a strong negative correlation with winter values for the North Atlantic Oscillation Index and mean winter temperature. Variations in a longer term stream nitrate record may be linked to the length of time the soil profile remains frozen during the winter. These factors could be influenced by climate changes. Land use in the areas may change due to external climate-driven changes such as expansion of agriculture into upland valleys, for food or biofuels and this could lead to increased leaching of nutrients (Reed et al., 2009). 


\section{$2.3 \quad$ Other nitrogen sources}

In urban areas, industrial and municipal discharges may increase loads of nutrients and other contaminants from both surface infrastructure and from the sewerage system. Urbanisation changes the natural pattern of recharge with increased recharge from mains water, leaking sewers and pluvial drains (Morris et al., 2006). Built areas and impervious surfaces change the scope for local precipitation to enter the aquifer. The impact of relatively modern suburban areas appears to be modest (Morris et al., 2006) whereas older urban areas with a longer history show a greater impact (Wakida and Lerner, 2005).

In the UK the majority of sewage effluent is treated and discharged to surface water. The impact to groundwater from sewage may therefore be minimised. This impact may still be influenced by climate change in the same way as surface water. In a surface water study in Maryland, USA, Kaushal et al. (2008) showed that urban areas become larger sources of N pollution during periods of variable rainfall, with high export during high flow conditions. From stream data they assessed that $\mathrm{N}$ urban areas export to surface water lay between agricultural areas and forests. There is insufficient data to show whether this is also true for groundwater.

Davis (1996) considered that recycling of sewage sludge to agricultural land was likely to be a major future disposal option, although environmental pressures on sludge recycling to land could lead to restrictions on applications in terms of $\mathrm{N}$ content. Inappropriate application times or rates may lead to poor utilisation by crops and, thus, to nitrate leaching and contamination of water supplies (Shepherd, 1996). Climate change pressures currently encourage the production of biofuels and Moffat et al. (2001) tested sewage sludge application and waste water irrigation for such production, but did not evaluate $\mathrm{N}$ leaching.

Urban areas are considered to be hot spots of environmental change (Grimm et al., 2008a) but our knowledge of ecosystem responses to urbanisation is based on only a few case studies (Grimm et al., 2008b). Urban infrastructure, such as water supply and sanitation, will come under increased pressure from climate change (Ruth and Coelho, 2007). Potential impacts on urban water quality will come from changes in short-term rainfall intensity overwhelming drainage systems particularly for combined systems (Whitehead et al., 2009). There may also be damage to water supply and sewers from shrink/swell clays, landslides and subsidence, leading to leakage (Boyle et al., 2000; Hobbs et al., 2008). 
Aerial deposition represents another $\mathrm{N}$ source to the surface and thence to groundwater. Deposition of $\mathrm{N}$ compounds for the UK has been derived from vehicle and power station emissions, the largest source of oxidised $\mathrm{N}$, agriculture $\left(\mathrm{NH}_{3}\right.$ and $\left.\mathrm{N}_{2} \mathrm{O}\right)$ and nylon manufacture $\left(\mathrm{N}_{2} \mathrm{O}\right)$ (UKRG, 1994). Possible impacts could include both changes in emissions from agricultural sources and deposition pattern due to changes in weather. Predicted changes in the aerial deposition of oxidised $\mathrm{N}$ over Europe due to climate change are small and not very coherent due to the strong inter-annual variability (Langner et al., 2005).

\subsection{Summary}

Table 4 summarises the scale of possible changes in agricultural and non-agricultural sources and leaching processes. Whilst it is clear that climate change will have a significant impact on crop yields and areas, it remains difficult to predict what these will be and relate these directly to nitrate availability in the soil. For leaching processes the impacts are clearer with most changes leading to increased nitrate leaching.

Position of Table 4.

\section{Pathways}

For a pollutant to reach a receptor there must be a possible route; the pathways from the soil surface and factors controlling migration include:

- Soil infiltration (cracking, surface sealing)

- Migration through the unsaturated zone (depth to water table, fissure flow);

- Migration through the saturated zone (water levels, flow direction, permeability, single or dual porosity, karst development, travel time);

- Linkage between groundwater and the receptor if the receptor is not groundwater.

Where the receptor is groundwater, surface water or a groundwater-dependent ecosystem an important driver is the amount and distribution of recharge (Fig 3).

The predicted impacts of climate change on pathways for nitrate to reach receptors are described below using examples from the UK, whilst Table 5 summarises the findings of similar impact studies for other areas elsewhere in Europe and North America.

Position of Figure 3

Position of Table 5 


\subsection{Impact of climate and land use change on recharge and resources}

Groundwater recharge is not only controlled by the spatial and temporal variability in the major climate variables but also on land surface properties, the depth and hydraulic properties of the soils, and vegetation and understanding the relative importance of these factors is critical for estimating recharge rates and for assessing water quality (Şen, 2009).

Climate change may have both positive and negative impacts (Jyrkama and Sykes, 2007); increasing precipitation leads to increases in run-off, evapotranspiration and groundwater recharge; decreasing precipitation leads to decreases in recharge and falling water levels; increasing temperature reduces the amount of ground frost thus increasing winter recharge for a catchment in Ontario, Canada. Eckhardt and Ulbrich (2003) also predicted pronounced changes in the annual cycle of streamflow and groundwater recharge influenced by changes in the pattern of snowmelt. There may be also changes in the amount of runoff relative to recharge due to surface impermeablisation or periods of ground saturation.

There have been several relevant studies on the impact of climate change on recharge in the UK. These showed increasing recharge and water levels over the next few decades but becoming drier thereafter (Holman, 2006; Younger et al., 2002; Yusoff et al., 2002). Projected impacts of climate change on recharge and water resources for other areas are summarised in Table 5. These impacts are very variable but a common result is an enhanced contrast between winter and summer patterns.

Soil moisture depends on a balance between precipitation and evapotranspiration and the winter period when soils are at field capacity may be curtailed by longer periods of higher temperatures and lower precipitation. A change in cropping pattern or the introduction of new crops may also change soil moisture, and recharge. Fohrer et al. (2001) evaluated cropland using winter barley, mixed forest, grassland and fallow as examples using the SWAT model. The amount of ground cover is important for controlling spring run-off, the temperature determines the growing season, canopy storage and height determines evapotranspiration. A relatively limited impact was predicted on overall recharge. Elevated $\mathrm{CO}_{2}$ concentrations would lead to reduced stomatal conductance and therefore to reduced transpiration (Ducharne et al., 2007).

Cropping and stock management can have an impact on soil hydrology because access during wet periods can cause soil compaction and thus increased run-off (Holman et al., 2003). Soil structural degradation may be particularly related to late harvested crops such as maize, sugar 
beet, main crop potatoes and autumn sown crops. There is mounting evidence that the condition of temperate soils could change at a range of temporal scales in response to climate change with implications for future assessments of recharge (Rounsevell et al., 1999; Grieve, 2001). Potential changes could be:

- daily scale - possible reduction in soil water content;

- daily to annual scale- increased erodability due to increased shrink/swell behaviour and increased recharge due to fissure flow -decreased erodability due improved vegetation cover in upland area;

- decadal to centuries scale loss of organic content.

DeFries and Eshleman (2004) set out the difficulties of assessing the consequences of land use change to hydrological processes: generally short hydrological records, natural high variability of most systems, difficulties of 'controlling' land use change in catchments which are being monitored, the small number of controlled-scale experiments, and challenges in extrapolation. Remote sensing, field measurements and modelling studies may be needed to understand the mechanisms of impact (Stonestrom et al., 2009). An integrated approach to assessing the impacts of climate change on groundwater recharge showed that the significant sources of uncertainty in recharge estimation were in the direction and extent of changes in precipitation, temperature, coastal flooding, urbanisation and surface sealing, woodland creation and cropping and changes in cropping, rotations and management practices (Holman, 2006; Holman, 2007).

It is likely that with the increase in temperature and decrease in summer precipitation projected for south eastern areas of the UK that the requirement for agricultural irrigation will be increased. There is little in the UK literature on nitrate leaching from irrigated agriculture, although this issue has been long recognised elsewhere (Spalding and Exner, 1993; Watts and Martin, 1981). Nitrate leaching from irrigated agriculture depends on the irrigation regime, amount and timing of water applications as well as the amount of fertiliser used (Derby et al., 2009; Peralta and Stockle, 2002; Thompson et al., 2007), although the evidence can be contradictory. There could potentially be an increase in the amount of nitrate leached due to irrigation using nitrate-rich groundwater if this is not taken into account in the fertiliser balance. Guimerà (1998) showed that nitrate concentrations of up to $700 \mathrm{mg} \mathrm{L}^{-1}$ in a coastal area of Spain were due to recycling of groundwater for irrigation as well as fertiliser applications. Stigter et al. (2005) modelled nutrient recycling in an area of southern Portugal 
where concentrations reached $250 \mathrm{mg} \mathrm{L}^{-1}$ in groundwater and also showed irrigation with nitrate-rich water to contribute significantly to nitrate leaching. These study areas are warmer and drier than anticipated for the UK.

\subsection{Changes in infiltration through soils}

Deep shrinkage cracks in shrink/swell soils may serve as preferential flow channels and allow agricultural chemicals to rapidly move past the crop root zone to subsoil, potentially contaminating groundwater (Chen et al., 2002; Harris et al., 1994). Several aspects of the infiltration process in cracking soils have proven to be difficult to measure; seal/crust formation and properties, crack network patterns, preferential flow zones and contributions, and soil moisture determinations within the profile (Wells et al., 2003). For many soils, the physical changes that take place (such as swelling, sealing, shrinkage, and cracking) during and after rain following dry periods greatly affect the movement of water in the soil as the cracks develop deeper and transmit water to lower depths within the profile. The change in soil macroporosity in the shrink-swell clay soils when change in water content occurred had a greater impact on low-tension flow processes than the change in water content itself (Lin et al., 1998). The impact of climate change may be increased cracking during more frequent or prolonged dry periods and increased infiltration during more frequent intense rainfall events.

In addition to swelling and cracking, clay soils form a surface seal, which also greatly affects infiltration (Wells et al., 2003). Surface sealing occurs due to the impact of raindrops on the surface of the soil, causing compaction, and settling of fine-grained detached material on the surface of the soil, effectively clogging the micropores. There may also be a breakdown of aggregates and the dispersion of clay material as a result of rapid wetting resulting in a change in soil permeability.

\subsection{Impact of aquifer pathways on nitrate transport}

The patterns of groundwater flow in aquifers can be considered as a distribution with one end member being flow through fractures and the other being intergranular movement through the pores of the matrix. In fractured aquifers, where the intergranular effective porosity is low, storage of water is limited. The recharge mechanism is similar under any recharge conditions with water moving rapidly through fractures and the consequent large impact of recharge volume of recharge on water levels. We could therefore expect to see increased differences between winter and summer water levels. Large seasonal variations in water table elevation would be anticipated and also clear and rapid responses to extreme events. 
As an example, in the UK Lincolnshire Limestone, groundwater movement is almost entirely by fracture flow along well-developed bedding plane fractures and joints (Allen et al., 1997). Often seasonal head differences are large, caused by the aquifer responding rapidly to recharge, as enhanced fractures allow run-off to enter the aquifer and be rapidly transferred down the hydraulic gradient. In some parts of the aquifer, a rapid increase of transmissivity with water table elevation can be observed (Smith, 1979) implying larger or more frequent fractures in the upper part of the aquifer.

In general nitrate concentrations follow a similar seasonal pattern to water levels. Beeson and Cook (2004) showed that nitrate in abstracted groundwater from the Lincolnshire Limestone decreased during periods of low water levels. This could be interpreted as a loss of rapid routes to points of abstraction for high nitrate modern recharge in the upper part of the aquifer due to the low water level.

For the other end member, purely intergranular aquifers, with large water storage in the pore spaces and few fractures, we would expect to see the opposite with very limited fluctuations in both water levels and nitrate concentrations. There are few important aquifers of this type in the UK and for the major sandstone aquifers fracture flow also has a significant role. Whilst water movement in the Permo-Triassic sandstone is predominantly intergranular, albeit controlled by considerable vertical heterogeneity and horizontal anisotropy, there is some fracture conductivity, which can dominate where there is extensive connectivity (Allen et al., 1997). Water levels and nitrate concentrations in the Permo-Triassic sandstone aquifer generally show relatively small seasonal fluctuations.

In dual-porosity aquifers, such as the Chalk, the hydraulic properties are complex and result from a combination of matrix and fracture properties (Allen et al., 1997). Chalk pore throats are small, restricting water movement and the fracture distribution is not uniformly distributed either geographically or with depth. Water movement through the unsaturated profile is determined by the intensity and duration of rainfall, antecedent conditions and the hydraulic conductivity of the profile and will have important implications for solute transport. In addition to changes in flow path giving access to a greater percentage of shallow high nitrate water there may also be winter preferential flow from the base of the soil bringing high nitrate water directly to the water table or water table rise from water entering elsewhere in the catchment flushing out stored nitrate from porewater. 
Sugita and Nakane (2007) have examined the effects of rainfall patterns on transport of nitrate in dual porosity media simulated by sand with artificial macropores. They showed that the proportion of solute moving by preferential flow increased with the amount of artificial rainfall. For lower amounts of rainfall some nitrate appeared to be removed by denitrification. For the Pacific region they estimated that the chance of nitrate leaching could increase by perhaps $25 \%$ in due to higher frequencies of heavier rainfall events resulting from climate change.

Therefore we speculate that for fractured aquifers an increase of intensive winter recharge as predicted by climate change models could lead to both increased winter preferential flow and an increase in water levels opening shallow rapid pathways to the receptor. Both of these could lead to at least a seasonal increase in nitrate concentrations in abstracted water. However, looking at the balance of nitrate overall, we need to evaluate the impacts of increased rainfall and increased dilution on nitrate concentrations. Changes in the flow path within the aquifer due to increased rainfall alone will not affect the gross mass present in groundwater.

\section{$4 \quad$ Receptors}

Groundwater provides water for public supply, industry and irrigation, baseflow support to surface water and aquatic ecosystem health (Lerner and Harris, 2009). Under the Water Framework Directive $(2000 / 60 / E C)$, receptors, in terms of chemical status, include the groundwater body itself, drinking water abstractions, associated surface waters and directly dependent ecosystems. Each of these can be affected by nitrate. The RegIS approach takes this a step further and assesses the impact on biodiversity (Holman et al., 2008).

Factors potentially involved in the relationship between groundwater body nitrate concentrations and receptor concentrations are the relative quantity and quality of waters exchanged between ground and surface waters. Any climate change impacts which effectively increase nitrate leaching to groundwater could therefore have very serious implications on other receptors.

Under the Groundwater Directive (2006/118/EC) and Nitrate Directive (91/676/EEC), the standard for nitrate is already set at $50 \mathrm{mg} \mathrm{L}^{-1}$. For other pollutants (except pesticides) quality standards (threshold values) are derived by considering the risk of failure to achieve the environmental objectives, associated with surface water and wetlands. 


\subsection{Abstracted groundwater}

Nitrate is already widespread in the aquifers of the UK often at elevated concentrations (Rivett et al., 2007). The average groundwater nitrate concentration in England has been shown to be rising at $0.34 \mathrm{mg} \mathrm{NO} \mathrm{L}^{-1} \mathrm{yr}^{-1}$ with the greatest trends in the Lincolnshire Limestone $\left(0.96 \mathrm{mg} \mathrm{NO}_{3} \mathrm{~L}^{-1} \mathrm{yr}^{-1}\right.$ and lowest in the Magnesian limestone aquifer (Stuart et al., 2007). Average trends for the major Chalk and Sherwood Sandstone aquifers were 0.38 and $0.44 \mathrm{mg} \mathrm{NO}_{3} \mathrm{~L}^{-1} \mathrm{yr}^{-1}$ respectively. In $2000,34 \%$ of sites analysed exceeded the $50 \mathrm{mg} \mathrm{L}^{-1}$ standard. If present trends continue, $41 \%$ of groundwater sources could exceed the standard by 2015 (Stuart et al., 2007). Under current climate conditions and agricultural practices concentrations are predicted to continue to rise in the UK Chalk aquifer (Wang et al., in press). These trends could be influenced by climate change both by changes in nitrate leaching and by changes in amount and timing of recharge and by the soil and aquifer pathway.

Groundwater nitrate concentrations show seasonal fluctuations, and these can be considerable for fractured aquifers, such as the Lincolnshire Limestone (Stuart and Kinniburgh, 2005). Seasonal behaviour depends on the mechanism of transmission of water from the surface to the water table, i.e. the pathway. Impacts on soil and aquifer pathways could therefore affect seasonal concentrations in aquifers.

\subsection{Surface water, wetlands and groundwater-dependent ecosystems}

Groundwater provides baseflow to rivers and supports a large number of wetlands. The Base Flow Index (BFI) is used as a measure of the baseflow characteristics of river catchments and has been shown to be a function of the hydraulic characteristic of the geological units within the catchment (Bloomfield et al., 2009). BFI provides a systematic way of assessing the average proportion of base flow in the total run-off of a catchment. Long-term average fluxes of nitrate from groundwater to surface water may be affected by long-term changes in groundwater heads; however, potential changes in seasonal and extreme groundwater heads will also have an effect on fluxes of nitrate from groundwater to surface waters. Changes in the seasonal distribution of recharge may have a critical effect on low flows in rivers supported by baseflow, but rivers supported by slowly responding aquifers may show a considerable delay in response (Wilkinson and Cooper, 1993; Peters et al., 2006).

The hyporheic zone has several roles including bank storage for flood water and a buffer zone and filter for nutrient fluxes (Smith et al., 2008). Where residence times are sufficiently 
long and there are potential electron donors available denitrification can occur in this zone (Puckett et al., 2008). Krause et al. (2009) showed that the distribution of the low redox zone can be very variable. However there are no catchment-scale or experimental data which demonstrate that this zone is effective in mitigating pollutant loads in managed landscapes (Smith et al., 2008). Sprenger et al. (2011) found that bank filtration processes are vulnerable to climate change due to the drastically shortened travel time during flood events.

Surface water is particularly sensitive to $\mathrm{N}$ and so as groundwater and its dissolved nitrate discharges into surface water its ecology can be adversely affected, particularly in association with phosphate, leading to eutrophication (Lerner and Harris, 2009). Assessing the impacts of eutrophication is not straightforward as it depends on light conditions, temperature, mean residence time and flow conditions as well as nutrient loading. Shallow lakes are particularly susceptible to eutrophication (Whitehead et al., 2009). Changes in the groundwater-surface water relationship, such as those resulting from climate change will have the potential for causing negative impacts on groundwater dependent ecosystems.

Individual plant species responses to stressors are also likely to be influenced by the hydrologic and geomorphologic characteristics of different wetland classes (Mahaney et al., 2009). Also the toxic limits for nitrate in groundwater are likely to be much lower for some invertebrates than the drinking water limit, perhaps nearer to $2 \mathrm{mg} \mathrm{L}^{-1} \mathrm{NO}_{3}-\mathrm{N}$ (Camargo and Alonso, 2006; Camargo et al., 2005; Hinsby et al., 2008). The threshold value for estuarine transitional waters for dissolved $\mathrm{N}$ is $0.28 \mathrm{mg} \mathrm{l}^{-1}$ (UKTAG, 2008).

\subsection{Atmosphere}

Concentrations of $\mathrm{N}_{2} \mathrm{O}$ in the troposphere are increasing and this has raised concerns that $\mathrm{N}_{2} \mathrm{O}$ could destroy stratospheric ozone concentrations (Jaffe, 1992). $\mathrm{N}_{2} \mathrm{O}$ emissions to the atmosphere can also contribute to radiative climatic forcing (Conen et al., 2000). $\mathrm{N}_{2} \mathrm{O}$ emissions have been attributed to agricultural pollution, from denitrification of nitrate (Puckett et al., 2011). However $\mathrm{N}_{2} \mathrm{O}$ can be an intermediate in both nitrification and denitrification processes (Jaffe, 1992). In soils the denitrification mechanism appears to be predominant and is related to soil parameters such as temperature and water-filled pore space as well as soil mineral $\mathrm{N}$ content (Conen et al., 2000). Mørkved et al. (2006) showed it was also influenced by the freeze-thaw cycle with high emissions during frozen periods.

$\mathrm{N}_{2} \mathrm{O}$ can also be emitted from water. Mühlherr and Hiscock (1998) found very high concentrations of $\mathrm{N}_{2} \mathrm{O}$ in groundwater from the most important limestone aquifers in the UK. 
The correlations between $\mathrm{N}_{2} \mathrm{O}, \mathrm{NO}_{3}$ and dissolved oxygen, as well as the spatial distribution of these chemical parameters, were used to identify nitrification processes in the unsaturated zone as the main $\mathrm{N}_{2} \mathrm{O}$ production mechanism probably strongly supplemented by nitrogenous compounds from anthropogenic land applications. $\mathrm{N}_{2} \mathrm{O}$ production in the saturated zone was less substantial and was possibly denitrification mediated.

Destouni and Darracq (2009) showed that for a Swedish catchment the subsurface contribution to atmospheric $\mathrm{N}_{2} \mathrm{O}$ was similar to that from surface water, and that these together were in the same order as $\mathrm{N}$ from deposition. They suggested that climate change may affect the nutrient attenuation and transformation rates.

\section{Discussion}

\subsection{Balancing the factors}

The principal impacts of climate change are shown to be changes in rainfall amounts, changes in intensity of rainfall, increased temperature, added to which are the direct impacts of increased atmospheric $\mathrm{CO}_{2}$. There are a range of competing consequential factors which control the concentration of groundwater nitrate at a receptor: changes in agriculture, soil mineralisation, recharge, leaching and groundwater pathway processes. Individual processes are well-studied but it remains difficult to assess the overall impact.

There are a few published studies which attempt to relate temperate climate change to predicted changes in nitrate concentrations in groundwater or at other receptors directly (De Jong et al., 2008; Ducharne et al., 2007; Holman et al., 2005b; Jackson et al., 2007; Whitehead et al., 2009). Holman et al. (2005b) indicate that the net impact is different for different areas, with nitrate leaching reduced in areas where agricultural production is lost due to increase droughts or floods, such as East Anglia, and increased in those where climate changes bring improved conditions and agricultural expansion, such as northwest England. De Jong et al. (2008) concluded that climate scenarios did not change $\mathrm{N}$ leaching very much and greater perturbations to climate, for example, to winter rainfall or to climate change driven agricultural intensification, would be required. In contrast, Ducharne et al. (2007) showed that for the Seine Basin under current practices the aquifer concentration would increase by $50 \%$ from the present. Under a moderate to high emissions scenario this could be as much as $100 \%$. Overall with the inherent difficulties of estimating key parameters in all of these studies predict that the impact on nitrate leaching to groundwater is likely to be within the margins of uncertainty. 


\subsection{Other factors}

There are many other influences on the amount of nitrate in groundwater and its impact on receptors, such as management practices. There may be both intended and unintended consequences of management practices which are controlled by regulation and subsidy. For example, the existence of a subsidy will lead to increased application of lime to upland catchments to mitigate the effect of acidification. This may have the unintended consequence of increasing nitrate leaching. Other measures, such as those imposed by the identification of Nitrate Vulnerable Zones are intended to alter the amount of nitrate lost to groundwater. The effects of these and similar measures may have an effect which masks the effect of climate change on nitrate leaching.

Measures have been taken in the UK to reduce nitrate pollution of ground and surface water by establishing nitrate sensitive areas (NSAs) and subsequently nitrate vulnerable zones (NVZs), where agricultural usage of nitrogenous fertilisers is regulated. There have been very few studies of the effectiveness of these measures in the UK. Lord et al. (1999) and Silgram et al. (2005) considered the success of NSAs in terms of the nitrate concentration of soil water in fields within an NSA and coupling this data with a nitrate transport model. This suggested a possible decline of nitrate leaching through the root zone but the study was not long enough to show a decline in abstracted groundwater. For a series of NVZs in England Worrall et al. (2009) found that about two thirds of NVZs showed no significant improvement in surface water concentrations even after 15 years, and about one third appeared to be worse relative to a control catchment. The average improvement relative to a control due to $\mathrm{NVZ}$ designation was $0.02 \pm 0.08 \mathrm{mg} \mathrm{N} \mathrm{L}^{-1} \mathrm{yr}^{-1}$. With ongoing improvements to $\mathrm{N}$ management under Good Agricultural Practice (Defra, 2009) it may be difficult in the future to identify the component due to climate change.

\subsection{Limitations on this approach}

The simple and linear Source-Pathway-Receptor approach derived from the N cycle does not deal adequately with interactions between the elements in a number of important respects:

- it assumes that the Source, Pathway and Receptor are independent;

- it does not allow the relative significance of the impacts to be assessed, for example an increase in $\mathrm{N}$ leaching is not necessarily of importance if the recharge increases such that the concentration of $\mathrm{N}$ in the recharge decreases;

- it also does not allow for other feedbacks in the system such as the contribution of $\mathrm{N}$ from surface water to groundwater during interactions; 
- it does not allow for changes in the route of removal of $\mathrm{N}$ from soils directly to surface water thus not impacting on groundwater.

However we believe that it provides a valuable framework to allow the individual elements of this complex system to be assessed.

\section{$5.4 \quad$ Future issues}

Climate change can affect various socio-economic sectors such as tourism, trade and industry, as well as agriculture. Other factors not covered by this study could therefore have an important role in affecting nitrate concentrations in the future. It is likely that the main impacts of climate change on agriculture will be economic (Holman et al., 2005a). This will drive continued loss of grassland as arable farming becomes viable in new areas and other changes driven by lack of irrigation water. As pressures on water become generally greater land management changes may need to be made to increase recharge, such as direct drilling rather than conventional autumn cultivation, and artificial recharge may be considered (Holman et al., 2005a).

This paper raises challenging issues regarding the need for and approaches to adaptation in the context of climate change. Adapting to climate change can be done in anticipation of climate change impacts (anticipatory adaptation where proactive steps are taken) or in response to climate events (reactive adaptation) (Binder et al., 2010). Anticipatory adaptation occurs when governments, businesses, or private citizens take proactive steps to reduce the negative consequences of projected climate change impacts and can also be used to maximize the benefits of climate change, such as a longer growing season (Binder et al., 2010).

Smit and Skinner (2002) set out four main types of adaptation options for agriculture in Canada:

1. Technological developments for crops, weather/climate information systems and resource management innovations, including irrigation;

2. Government programmes for agricultural subsidies and insurance to provide income stabilisation;

3. Farm production practices including intensification and diversification of crops and livestock, and changing land use;

4. Farm financial management including investment in crop futures. 
They also emphasise the need for information provision to stimulate adaptation initiatives. These types would also be applicable to policies related to nitrate leaching.

Given the major impact uncertainties, robust adaptation options are needed which are beneficial irrespective of the actual impacts of climate change. In the UK there has already been a shift away from climate change impact assessment to identifying practical adaptation measures (Wilby et al., 2006). Such measures will need to take into account environmental, technological, economic, institutional and cultural characteristics (Tanaka et al., 2006; PahlWostl, 2007; Medellín-Azuara et al., 2008).

Managing and adapting water demand has received considerable attention. Holman and Trawick (2011) discuss adaptive capacity to groundwater abstraction management. They identified key elements as better horizontal and vertical integration within resource management, making better use of resources, embedding adaptation at multiple scales, facilitating local groups promoting efficient water use and not least controlling abstractions. Other elements suggested by Mohapatra and Mitchell (2009) were a differential pricing structure, conservation education, pollution prevention and water recycling, as well as effective information management. Crabbé and Robin (2006) examined likely local institutional barriers to climate change adaptation for Eastern Ontario.

The economic cost of such measures needs to be related to the existing uncertainties in the climate change scenarios (Middelkoop et al., 2001). These authors recommend a flexible policy in water management planning and design where anticipatory adaptive measures in response to climate change impacts are undertaken in combination with ongoing activities.

Baker and Murray (2009) attempt to model the interactions of climate policy and groundwater management. They examined the impact of a range of greenhouse gas mitigation incentives, aimed at the agricultural sector, on the derived demand for groundwater. They show that a regional solution to reducing emissions both from fossil fuel use for groundwater extraction and from $\mathrm{N}_{2} \mathrm{O}$ emissions from fertilisers would also benefit groundwater resources and possibly quality. Table 6 sets out a summary of their findings for both water management and nitrate leaching in terms of marginal cost or price effects. The main sources of uncertainty were identified as policy uncertainty and the magnitude of the policy stimuli.

Position of Table 6 
Such complex issues will demand a multidisciplinary approach and this may become a major issue (DeFries and Eshleman, 2004). These authors state that a wide collaboration will be needed between disciplines such as remote sensing, socio economic studies, ecology and hydrology. Advances in remote sensing, data handling and processing, and predictive modelling now allow such research to become a practical option. Research aimed towards explicit understanding of these interactions will be needed to provide necessary input to decisions that must balance trade-offs between the positive benefits of land-use change and potential negative consequences. Cline (2007) identifies another factor, international trade, as a future potential modifier on the agricultural sector but thinks that this would not be effective for a global scale problem.

\section{Conclusions}

Nitrate concentrations in groundwater are already a serious problem with many groundwater abstractions containing nitrate concentration which exceed the drinking water limit. Under current climate conditions and agricultural practices concentrations are predicted to continue to rise.

Climate changes such as changes in temperature, precipitation amounts and distribution, and the underlying increases in atmospheric $\mathrm{CO}_{2}$ concentrations will impact on both soil processes and agricultural productivity. This has been well-studied in terms of crop yields and potential changes in cultivars, crop type and the northwards extension of cropping area. However, the impacts of these changes on the $\mathrm{N}$ source term remain difficult to predict. Studies of soil processes suggest climate change is likely to lead to increased nitrate leaching from the soil. Other source terms include non-agricultural sources, such as urban areas and atmospheric deposition.

Climate change will also affect the hydrological cycle with changes to recharge, groundwater levels and resources and flow processes. The predicted impacts are variable but many predictions suggest an overall decrease in recharge and a fall in water levels and almost all predict an enhanced seasonal variation in water levels. This will impact on concentrations of nitrate in abstracted water and other possibly more-sensitive receptors such as groundwater dependent wetlands on an annual timescale. The longer term impact on aquifer pathways still needs to be evaluated. 
The implications for nitrate leaching to groundwater as a result of climate changes are not yet well enough understood to be able to make useful predictions without a lot of site-specific data. The few studies which address the whole cycle show likely nitrate leaching ranging from limited increases to a possible doubling of aquifer concentrations by 2100 if changes to agricultural practice are not made. The inherent difficulties of estimating key parameters mean that these predictions are within the margins of uncertainty. The predicted impact of climate change on nitrate concentrations appears to be less than the predicted changes to concentrations resulting from measures to reduce agricultural nitrate leaching.

The main future climate change impacts on agriculture may be economic. A range of adaption measures need to be identified and these need to be derived through interdisciplinary including collaboration between regulators, the farming community, government departments and scientists.

\section{Acknowledgements}

This paper is published by permission of the Executive Director of the British Geological Survey. The authors are grateful to Dr Rob Ward and to two anonymous reviewers for constructive review comments.

\section{References}

Aber JD, Ollinger SV, Driscoll CT, Likens GE, Holmes RT, Freuder RJ, et al. Inorganic nitrogen losses from a forested ecosystem in response to physical, chemical, biotic, and climatic perturbations. Ecosystems 2002;5:648-58.

ADAS. Informal Seminar on nitrate leaching and Nitrate Sensitive Areas. Water Research Centre, Wallingford, 1991.

Aguilera H, Murillo JM. The effect of possible climate change on natural groundwater recharge based on a simple model: a study of four karstic aquifers in SE Spain. Environ Geol 2009;57:963-74.

Allen DJ, Brewerton LJ, Coleby LM, Gibbs BR, Lewis MA, MacDonald AM, et al. The physical properties of major aquifers in England and Wales. British Geological Survey Technical Report WD/97/34 and Environment Agency R\&D Publication 8, 1997.

Allott TEH, Curtis CJ, Hall J, Harriman R, Battarbee RW. The impact of nitrogen deposition on upland surface waters in Great Britain: A regional assessment of nitrate leaching. Water Air Soil Poll 1995;85:297-302.

Baker JS, Murray BC. Groundwater management in the presence of greenhouse gas mitigation: Incentives for agriculture. Agricultural and Applied Economics Association, AAEA and ACCI Joint Annual Meeting, July 26-29, 2009, Milwaukee, Wisconsin, 2009. 
Ball AS, Pocock S. The effects of elevated atmospheric carbon dioxide concentrations on nitrogen cycling in a grassland ecosystem. In: Wilson WS, Ball AS, Hinton RH, editors. Conference on Managing Risks of Nitrates to Humans and the Environment. Royal Society of Chemistry Colchester, England, 1997, pp. 110-8.

Beaudoin N, Saad JK, Van Laethem C, Machet JM, Maucorps J, Mary B. Nitrate leaching in intensive agriculture in Northern France: Effect of farming practices, soils and crop rotations. Agr Ecosys Environ 2005;111:292-310.

Beeson S, Cook MC. Nitrate in groundwater: a water company perspective. Q J Eng Geol Hydroge 2004;37:261-70.

Betts RA, Boucher O, Collins M, Cox PM, Falloon PD, Gedney N, et al. Projected increase in continental runoff due to plant responses to increasing carbon dioxide. Nature 2007;448:1037-41.

Binder L, Barcelos J, Booth D, Darzen M, Elsner M, Fenske R, et al. Preparing for climate change in Washington State. Clim Change 2010;102:351-76.

Bisgrove R, Hadley P. Gardening in the global greenhouse: The impacts of climate change on gardens in the UK. Technical Report UKCIP, Oxford, 2002.

Bloomfield JP, Allen DJ and Griffiths KJ. 2009. Examining geological controls on baseflow index (BFI) using regression analysis: An illustration from the Thames basin, UK. J. Hydrology, 373, 164-176.

Bloomfield JP, Williams RJ, Gooddy DC, Cape JN, Guha P. Impacts of climate change on the fate and behaviour of pesticides in surface and groundwater--a UK perspective. Sci Tot Environ 2006;369:163-77.

Borken W, Matzner E. Reappraisal of drying and wetting effects on $\mathrm{C}$ and $\mathrm{N}$ mineralization and fluxes in soils. Glob Change Biol 2009;15:808-24.

Bowman RA, Nielsen DC, Vigil MF, Aiken RM. Effects of sunflower on soil quality indicators and subsequent wheat yield. Soil Sci 2000;165:516-22.

Boyle J, Stow R, Wright P. INSAR imaging of London surface movement for structural damage management and water resource conservation ESA ERS/Envisat Symposium http://earth.esa.int/pub/ESA_DOC/gothenburg/381boyle.pdf

Brouyère S, Carabin G, Dassargues A. Climate change impacts on groundwater resources: modelled deficits in a chalky aquifer, Geer basin, Belgium. Hydrogeol J 2004; 12: 123-34.

Callesen I, Borken W, Kalbitz K, Matzner E. Long-term development of nitrogen fluxes in a coniferous ecosystem: Does soil freezing trigger nitrate leaching? J Plant Nutr Soil Sci 2007;170:189-96.

Camargo JA, Alonso A, Salamanca A. Nitrate toxicity to aquatic animals: a review with new data for freshwater invertebrates. Chemosphere 2005;58:1255-67.

Camargo JA, Alonso A. Ecological and toxicological effects of inorganic nitrogen pollution in aquatic ecosystems: a global assessment. Environ Int 2006;32:831-49.

Charlton R, Moore S, Sweeney J, Fealy R. Climate change and water resources in Ireland: initial investigations using downscaled GCMS and hydrological modelling techniques. Cuadernos Invest Geog 2001;27:125-35.

Chen C, Roseberg RJ, Selker JS. Using microsprinkler irrigation to reduce leaching in a shrink/swell clay soil. Agr Water Manage 2002;54:159-71. 
Cline WR. Global Warming and Agriculture: Impact Estimates by Country. Washington DC, USA Centre for Global Development \& Peterson Institute for International Economics 2007.

Conen F, Dobbie KE, Smith KA. Predicting $\mathrm{N}_{2} \mathrm{O}$ emissions from agricultural land through related soil parameters. Glob Change Biol 2000;6:417-26.

Crabbé P, Robin M. Institutional adaptation of water resource infrastructures to climate change in Eastern Ontario. Clim Change 2006;78:103-33.

Cresser MS, Aitkenhead MJ, Mian IA. A reappraisal of the terrestrial nitrogen cycle: What can we learn by extracting concepts from Gaia theory? Sci Total Environ 2008;400:344-55.

Cuny H, Wery J, Gaufres F. A simple indicator for diagnosing nitrate leaching risk below the root zone using the Tensionic tensiometers. Agronomie 1998;18:521-35.

Davis RD. The impact of EU and UK environmental pressures on the future of sludge treatment and disposal. Water Environ J 1996;10 65-9.

De Jong R, Qian B, Yang JY. Modelling nitrogen leaching in Prince Edward Island under climate change scenarios. Can J Soil Sci 2008;88:61-78.

DEFRA. Post-conciliation partial regulatory impact assessment. Groundwater proposals under Article 17 of the Water Framework Directive. Draft Final Report. Department for the Environment, Food and Rural Affairs, London, 2006.

DEFRA. Protecting our Water, Soil and Air: A Code of Good Agricultural Practice for farmers, growers and land managers. The Stationery Office, Norwich, 2009.

DeFries R, Eshleman KN. Land-use change and hydrologic processes: a major focus for the future. Hydrol Proc 2004;18:2183-6.

Derby NE, Casey FXM, Kinghton RE. Long-term observations of vadose zone and groundwater nitrate concentrations under irrigated agriculture. Vadose Zone J 2009;8:290300 .

Destouni G, Darracq A. Nutrient cycling and $\mathrm{N}_{2} \mathrm{O}$ emissions in a changing climate: the subsurface water system role. Environ Res Let 2009;4:035008.

Di HJ, Cameron KC. Nitrate leaching in temperate agroecosystems: sources, factors and mitigating strategies. Nutr Cycl Agroecosys 2002;64:237-56.

Downing TE, Harrison PA, Butterfield RE, Lonsdale KG. Climate change, climatic variability and agriculture in Europe. Environmental Change Institute, University of Oxford, 2000, pp. 446.

Drake BG, Gonzàlez-Meler MA, Long SP. More efficient plants: A consequence of rising atmospheric $\mathrm{CO}_{2}$ ? An Rev Plant Phys Plant Mol Biol 1997;48:609-39.

Ducharne A, Baubion C, Beaudoin N, Benoit M, Billen G, Brisson N, et al. Long term prospective of the Seine River system: Confronting climatic and direct anthropogenic changes. Sci Tot Environ 2007;375:292-311.

Eckersten H, Blombäck K, Kätterer T, Nyman P. Modelling C, N, water and heat dynamics in winter wheat under climate change in southern Sweden. Agriculture, Ecosys Environ 2001;86:221-35.

Eckhardt K, Ulbrich U. Potential impacts of climate change on groundwater recharge and streamflow in a central European low mountain range. J Hydrol 2003;284: 244-52. 
Emmett BA, Beier C, Estiarte M, Tietema A, Kristensen HL, Williams D, et al. The response of soil processes to climate change: Results from manipulation studies of shrublands across an environmental gradient. Ecosys 2004;7:625-37.

Fohrer N, Haverkamp S, Eckhardt K, Frede HG. Hydrologic response to land use changes on the catchment scale. Phys Chem Earth Pt B 2001;26:577-82.

Fowler HJ, Blenkinsop S, Tebaldi C. Linking climate change modelling to impacts studies: recent advances in downscaling techniques for hydrological modelling. Int J Clim 2007;27: 1547-78.

Francis GS, Bartley KM, Tabley FJ. The effect of winter cover crop management on nitrate leaching losses and crop growth. J Agr Sci 1998; 131: 299-308.

Gasser M, Caron J, Lagace R, MR L. Predicting nitrate leaching under potato crops using transfer functions. J Environ Qual 2003;32:1464-1473.

Gedney N, Cox PM, Betts RA, Boucher O, Huntingford C, Stott PA. Detection of a direct carbon dioxide effect in continental river runoff records. Nature 2006;439: 835-8.

Goderniaux P, Brouyère S, Fowler HJ, Blenkinsop S, Therrien R, Orban P, et al. Large scale surface-subsurface hydrological model to assess climate change impacts on groundwater reserves. J Hydrol 2009;373:122-38.

Goulding K. Nitrate leaching from arable and horticultural land. Soil Use Manage 2000;16:145-51.

Goulding KWT, Poulton PR, Webster CP, Howe MT. Nitrate leaching from the Broadbalk Wheat Experiment, Rothamsted, UK, as influenced by fertilizer and manure inputs and the weather. Soil Use Manage 2000;16:244-50.

Grieve IC. Human impacts on soil properties and their implications for the sensitivity of soil systems in Scotland. Catena 2001;42:361-74.

Grimm NB, Faeth SH, Golubiewski NE, Redman CL, Wu J, Bai X, et al. Global change and the ecology of cities. Science 2008a;319:756-60.

Grimm NB, Foster D, Groffman P, Grove JM, Hopkinson CS, Nadelhoffer KJ, et al. The changing landscape: ecosystem responses to urbanization and pollution across climatic and societal gradients. Front EcolEnviron 2008b;6:264-72.

Guimerà J. Anomalously high nitrate concentrations in ground water. Ground Water 1998;36:275-82.

Harris GL, Nicholls PH, Bailey SW, Howse KR, Mason DJ. Factors influencing the loss of pesticides in drainage from a cracking clay soil. J Hydrol 1994;159:235-53.

Henriques C, Holman I, Audsley E, Pearn K. An interactive multi-scale integrated assessment of future regional water availability for agricultural irrigation in East Anglia and North West England. Clim Change 2008;90: 89-111.

Herrera JM, Liedgens M. Leaching and utilization of nitrogen during a spring wheat catch crop succession. J Environ Qual 2009;38:1410-9.

Hinsby K, Condesso de Melo MT, Dahl M. European case studies supporting the derivation of natural background levels and groundwater threshold values for the protection of dependent ecosystems and human health. Sci Tot Environ 2008;401:1-20.

Hobbs P, Gibson A, Koor NP, Rees J, Price SJ, Harrison M, et al. Improved modelling and communication of urban risks: case studies from the United Kingdom and South-East Asia. 
European econference of the International Association for Engineering Geology, Madrid, Spain, 15-20 Sept 2008.

Holman IP, Loveland PJ. Regional climate change impacts in East Anglia and the North West (the RegIS project). Final Report of MAFF Project number CC0337 (available from www.ukcip,org.uk), 2001.

Holman IP, Hollis JM, Bramley ME, Thompson TRE. The contribution of soil structural degradation to catchment flooding: a preliminary investigation of the 2000 floods in England and Wales. Hydrol Earth Sys Sci 2003;7: 55-66.

Holman I, Nicholls R, Berry P, Harrison P, Audsley E, Shackley S, et al. A regional, multisectoral and integrated assessment of the impacts of climate and socio-economic change in the UK: Part II. Results. Clim Change 2005a;71:43-73.

Holman I, Rounsevell M, Shackley S, Harrison P, Nicholls R, Berry P, et al. A regional, multi-sectoral and integrated assessment of the impacts of climate and socio-economic change in the UK: Part 1 Methodology. Clim Change 2005b;71:9-41.

Holman IP. Climate change impacts on groundwater recharge-uncertainty, shortcomings, and the way forward? Hydroge J 2006;14:637-47.

Holman IP. Sources of uncertainty in climate change impacts on groundwater recharge. Eos Trans AGUI 2007; 88.

Holman I, Rounsevell M, Cojacaru G, Shackley S, McLachlan C, Audsley E, et al. The concepts and development of a participatory regional integrated assessment tool. Clim Change 2008;90:5-30.

Holman I, Tascone D, Hess T. A comparison of stochastic and deterministic downscaling methods for modelling potential groundwater recharge under climate change in East Anglia, UK: implications for groundwater resource management. Hydroge J 2009;17:1629-41.

Holman IP, Trawick P. Developing adaptive capacity within groundwater abstraction management systems. J Environ Manage 2011;92:1542-9.

Hulme M, Jenkins GJ. Climate change scenarios for the UK: scientific report. UKCIP Technical Report No.1 Climatic Research Unit, Norwich, 1998.

Hulme M, Jenkins GI, Lu X, Turnpenny JR, T.D. M, Jones RG, et al. Climate change scenarios for the United Kingdom: the UKCIP02 Scientific Report. Tyndall Centre for Climate Change Research, School of Environmental Sciences, University of East Anglia, Norwich, 2002.

Ineson P, Benham DG, Poskitt J, Harrison AF, Taylor K, Woods C. Effects of climate change on nitrogen dynamics in upland soils. 2. A soil warming study. Glob Change Biol 1998a;4:153-61.

Ineson P, Taylor K, Harrison AF, Poskitt J, Benham DG, Tipping E, et al. Effects of climate change on nitrogen dynamics in upland soils. 1. A transplant approach. Glob Change Biol 1998b;4:143-52.

IPCC. Climate Change 2007: Synthesis Report. Contribution of Working Groups I, II and III to the Fourth Assessment Report of the Intergovernmental Panel on Climate Change. Geneva, Switzerland: IPCC Secretariat, 2007.

Jackson CR, Meister R and Prudhomme C. Modelling the effects of climate change and its uncertainty on the UK Chalk groundwater resources from an ensemble of global climate model projections. J. Hydrol. 2011;Doi:10.1016/j.jhydrol.2010.12.028 
Jackson BM, Wheater HS, Wade AJ, Butterfield D, Mathias SA, Ireson AM, et al. Catchment-scale modelling of flow and nutrient transport in the Chalk unsaturated zone. Ecol Model 2007;209:41-52.

Jaffe DA. The nitrogen cycle. In: Butcher SS, Charlson RJ, Orians GH, Wolfe GV, editors. Global Biochemical Cycles. Academic Press, London, 1992, pp. 263-84.

Johnsson H, Larsson M, Mårtensson K, Hoffmann M. SOILNDB: a decision support tool for assessing nitrogen leaching losses from arable land. Environ Mod Software 2002;17:505-17.

Justes E, Mary B, Nicolardot B. Comparing the effectiveness of radish cover crop, oilseed rape volunteers and oilseed rape residues incorporation for reducing nitrate leaching. Nutr Cycl Agroecosys 1999;55:207-20.

Jyrkama MI, Sykes JF. The impact of climate change on spatially varying groundwater recharge in the Grand River watershed (Ontario). J Hydrol 2007;338:237-50.

Kaushal SS, Groffman PM, Band LE, Shields CA, Morgan RP, Palmer MA, et al. Interaction between urbanization and climate variability amplifies watershed nitrate export in Maryland. Environ Sci Technol 2008;42:5872-8.

Krause S, Heathwaite L, Binley A, Keenan P. Nitrate concentration changes at the groundwater-surface water interface of a small Cumbrian river. Hydrol Proc 2009;23:2195211.

Langner J, Bergström R, Foltescu V. Impact of climate change on surface ozone and deposition of sulphur and nitrogen in Europe. Atmos Environ 2005;39:1129-41.

Leirós MC, Trasar-Cepeda C, Seoane S, Gil-Sotres F. Dependence of mineralization of soil organic matter on temperature and moisture. Soil Biol Biochem 1999;31:327-35.

Lerner DN, Harris RC. The relationship between land use and groundwater resources and quality. Land Use Policy 2009;265:S265-73.

Lin HS, Mclnnes KJ, Wilding LP, Hallmark CT. Macroporosity and initial moisture effects on infiltration rates in vertisols and vertic intergrades. Soil Sci 1998;163:2-8.

Long SP, Ainsworth EA, Leakey ADB, Nösberger J, Ort DR. Food for thought: Lower-thanexpected crop yield stimulation with rising CO2 concentrations. Science 2006;312:1918-21.

Lord EI, Johnson PA, Archer JR. Nitrate Sensitive Areas: a study of large scale control of nitrate loss in England. Soil Use Manage 1999;15:201-7.

Lord EI, Anthony SG, Goodlass G. Agricultural nitrogen balance and water quality in the UK. Soil Use Manage 2002;18:363-9.

MAFF. Tackling nitrate from agriculture. MAFF Publications, London, 1999.

MAFF. Climate Change \& Agriculture in the United Kingdom. HMSO, 2000.

Mahaney WM, Wardrop DH, Brooks RP. Impacts of stressors on the emergence and growth of wetland plant species in Pennsylvania, USA. Wetlands 2009;24:538-49.

Matzner E, Borken W. Do freeze-thaw events enhance $\mathrm{C}$ and $\mathrm{N}$ losses from soils of different ecosystems? A review. Eur J Soil Sci 2008;59:274-84.

Maxwell RM, Kollet SJ. Interdependence of groundwater dynamics and land-energy feedbacks under climate change. Nature Geosci 2008;1:665-9. 
Medellín-Azuara J, Harou J, Olivares M, Madani K, Lund J, Howitt R, et al. Adaptability and adaptations of California's water supply system to dry climate warming. Clim Change 2008;87:75-90.

Middelkoop H, Daamen K, Gellens D, Grabs W, Kwadijk JCJ, Lang H, et al. Impact of climate change on hydrological regimes and water resources management in the Rhine Basin. Clim Change 2001;49:105-28.

Mitchell MJ, Driscoll CT, Kahl JS, Murdoch PS, Pardo LH. Climatic control of nitrate loss from forested watersheds in the Northeast United States. Environ Sci Technol 1996;30:260912.

Moffat AJ, Armstrong AT, Ockleston J. The optimization of sewage sludge and effluent disposal on energy crops of short rotation hybrid poplar. Biomass Bioenerg 2001;20:161-9.

Mohapatra S, Mitchell A. Groundwater demand management in the Great Lakes BasinDirections for new policies. Water Resour Manage 2009;23:457-475.

Monteith DT, Evans CD, Reynolds B. Are temporal variations in the nitrate content of UK upland freshwaters linked to the North Atlantic Oscillation? Hydrol Proc 2000;14:1745-9.

Morison JIL, Gifford RM. Stomatal sensitivity to carbon dioxide and humidity: A comparison of two $\mathrm{C}_{3}$ and two $\mathrm{C}_{4}$ grass species. Plant Physiol 1983;71:789-96.

Mørkved PT, Dörsch P, Henriksen TM, Bakken LR. $\mathrm{N}_{2} \mathrm{O}$ emissions and product ratios of nitrification and denitrification as affected by freezing and thawing. Soil Biol Biochem 2006;38:3411-20.

Morris B, Darling W, Cronin A, Rueedi J, Whitehead E, Gooddy D. Assessing the impact of modern recharge on a sandstone aquifer beneath a suburb of Doncaster, UK. Hydroge $\mathrm{J}$ 2006;14:979-97.

Mühlherr IH, Hiscock KM. Nitrous oxide production and consumption in British limestone aquifers. J Hydrol 1998;211:126-39.

Murphy JM, Sexton DMH, Jenkins GJ, Booth BBB, Brown CC, Clark RT, et al. UK Climate Projections Science Report: Climate change projections. Met Office Hadley Centre, Exeter, 2009.

Nadelhoffer K, Aber J, Melillo J. Seasonal patterns of ammonium and nitrate uptake in nine temperate forest ecosystems. Plant Soil 1984;80:321-35

Olesen JE, Bindi M. Consequences of climate change for European agricultural productivity, land use and policy. Eur J Agron 2002;16:239-62.

Olesen JE, Carter TR, Diaz-Ambrona CH, Fronzek S, Heidmann T, Hickler T, et al. Uncertainties in projected impacts of climate change on European agriculture and terrestrial ecosystems based on scenarios from regional climate models. Clim Change 2007;81:123-43.

Oliveira MM, Novo ME, Ferreira JPL. Models to predict the impact of the climate changes on aquifer recharge. In: Ferreira JPL, Viera JMP, editors. Water in Celtic Countries:

Quantity, Quality and Climate Variability. Proceedings of the Fourth Inter-Celtic Colloquium on Hydrology and Management of Water Resources, Guimaraes, Portugal, 4-11 July, 2005. vol. 310. IAHS, 2007

Owens LB, Malone RW, Shipitalo MJ, Edwards WM, Bonta JV. Lysimeter study of nitrate leaching from a corn-soybean rotation. J Environ Qual 2000;29:467-74. 
Pahl-Wostl C. Transitions towards adaptive management of water facing climate and global change. Water Resour Manage 2007;21: 49-62.

Parry M, Rosenzweig C, Iglesias A, Fischer G, Livermore M. Climate change and world food security: a new assessment. Glob Environ Change 1999;9:S51-67.

Peralta JM, Stockle CO. Dynamics of nitrate leaching under irrigated potato rotation in Washington State: a long-term simulation study. Agr Ecosys Environ 2002;88:23-34.

Peters E, Bier G, van Lanen HAJ and Torfs PJJF. 2006. Propagation and spatial distribution of drought in a groundwater catchment. J. Hydrol, 321, 257-75

Petry J, Soulsby C, Malcolm IA, Youngson AF. Hydrological controls on nutrient concentrations and fluxes in agricultural catchments. Sci Tot Environ 2002;294:95-110.

Prudhomme $\mathrm{C}$ and Davies $\mathrm{H}$. Assessing uncertainties in climate change impact analyses on the river flow regimes in the UK. Pargt1: baseline climate. 2009. Clim Change;93:177-95.

Puckett LJ, Zamora C, Essaid H, Wilson JT, Johnson HM, Brayton MJ, et al. Transport and fate of nitrate at the ground-water/surface-water interface. J Environ Qual 2008;37:1034-50.

Puckett LJ, Tesoriero AI, Dubrovsky NM. Nitrogen contamination of surficial aquifers-a growing legacy. Environ Sci Technol 2011;45:839-44.

Reed MS, Bonn A, Slee W, Beharry-Borg N, Birch J, Brown I, et al. The future of the uplands. Land Use Policy 2009;265:S204-16.

Rivett MO, Smith JWN, Buss SR, Morgan P. Nitrate occurrence and attenuation in the major aquifers of England and Wales. Q J Eng Geol Hydroge 2007;40:335-52.

Rounsevell MDA, Evans SP, Bullock P. Climate change and agricultural soils. Clim Change 1999;43:683-709.

Rozemeijer JC, Broers HP, Geer FCv, Bierkens MFP. Weather-induced temporal variations in nitrate concentrations in shallow groundwater. J Hydrol 2009;378:119-27.

RR. Climate change and land management. Rothampstead Research, 2009.

Rustad LE, Campbell JL, Marion GM, Norby RJ, Mitchell MJ, Hartley AE, et al. A metaanalysis of the response of soil respiration, net nitrogen mineralization, and aboveground plant growth to experimental ecosystem warming. Oecologia 2001;126:543-62.

Ruth M, Coelho D. Understanding and managing the complexity of urban systems under climate change. Clim Pol 2007;7:317-36.

Salo T, Turtola E. Nitrogen balance as an indicator of nitrogen leaching in Finland. Agr Ecosys Environ 2006;113:98-107.

Sardans J, Penuelas J, Estiarte M. Changes in soil enzymes related to C and N cycle and in soil $\mathrm{C}$ and $\mathrm{N}$ content under prolonged warming and drought in a Mediterranean shrubland. Appl Soil Ecol 2008;39:223-35.

Scibek J, Allen DM, Cannon AJ, Whitfield PH. Groundwater-surface water interaction under scenarios of climate change using a high-resolution transient groundwater model. J Hydrol 2007;333:165-81.

Scibek J, Allen DM. Modeled impacts of predicted climate change on recharge and groundwater levels. Water Resour Res 2006; 42:W11405.

Scott Angle J. Nitrate leaching losses from soybeans (Glycine max L. Merr.). Agr Ecosys Environ 1990;31:91-7. 
Şen Z. Global warming threat on water resources and environment: a review. Environ Geol 2009;57:321-9.

Shepherd MA. Factors affecting nitrate leaching from sewage sludges applied to a sandy soil in arable agriculture. Agr Ecosyst Environ 1996;58:171-85.

Sieling K, Kage H. N balance as an indicator of $\mathrm{N}$ leaching in an oilseed rape - winter wheat winter barley rotation. Agr Ecosys Environ 2006;115:261-9.

Silgram M, Waring R, Anthony S, Webb J. Intercomparison of national \& IPCC methods for estimating N loss from agricultural land. Nutr Cycl Agroecosys 2001;60:189-95.

Silgram M, Williams A, Waring R, Neumann I, Hughes A, Mansour M, et al. Effectiveness of the Nitrate Sensitive Areas Scheme in reducing groundwater concentrations in England. Q J Eng Geol Hydroge 2005; 38:117-27.

Sinclair TR. Mineral nutrition and plant growth response to climate change. J Exp Bot 1992;43:1141-6.

Skiba U, Fowler D, Smith KA. Nitric oxide emissions from agricultural soils in temperate and tropical climates: sources, controls and mitigation options. Nutr Cycl Agroecosys 1997;48:139-53.

Smit B, Skinner MW. Adaptation options in agriculture to climate change: A typology. Mitigation and Adaptation Strategies for Global Change. 7. Kluwer Academic Publishers, 2002, pp. 85-114.

Smith EJ. Spring discharge in relation to rapid fissure flow. Ground Water 1979;17:346-50.

Smith JWN, Bonell M, Gibert J, McDowell WH, Sudicky EA, Turner JV, et al. Groundwater-surface water interactions, nutrient fluxes and ecological response in river corridors: Translating science into effective environmental management. Hydrol Proc 2008;22:151-7.

Sommer SG, Hutchings N. Techniques and strategies for the reduction of ammonia emission from agriculture. Water Air Soil Poll 1995;85:237-48.

Spalding RF, Exner ME. Occurrence of nitrate in groundwater - a review. J Environ Qual 1993;22:392-402.

Sprenger C, Lorenzen G, Hülshoff I, Grützmacher G, Ronghang M, Pekdeger A. Vulnerability of bank filtration systems to climate change. Sci Total Environ 2011;409:65563.

Stonestrom DA, Scanlon BR, Zhang L. Introduction to special section on Impacts of Land Use Change on Water Resources. Water Resour Res 2009; 45,W00A00.

Stigter T, Almeida P, Dill AC, Ribeiro L. Influence of irrigation on groundwater nitrate concentrations in areas considered to have low vulnerability to contamination. In: Bocanegra E, Hernandez MA, Usunoff E, editors. Groundwater and Human Development. 6, 2005, pp. 69-85.

Stuart ME, Kinniburgh DG. Nitrate trends in groundwater. British Geological Survey Report IR/05/137, 2005.

Stuart ME, Chilton PJ, Kinniburgh DG, Cooper DM. Screening for long-term trends in groundwater nitrate monitoring data. Q J Eng Geol Hydroge 2007;40:361-76.

Sugita F, Nakane K. Combined effects of rainfall patterns and porous media properties on nitrate leaching. Vadose Zone J 2007;6:548-53. 
Tanaka S, Zhu T, Lund J, Howitt R, Jenkins M, Pulido M, et al. Climate warming and water management adaptation for California. Clim Change 2006;76:361-87.

Thompson RB, Martinez-Gaitan C, Gallardo M, Gimenez C, Fernandez MD. Identification of irrigation and $\mathrm{N}$ management practices that contribute to nitrate leaching loss from an intensive vegetable production system by use of a comprehensive survey. Agr Water Manage 2007;89:261-74.

Thomsen IK. Nitrate leaching under spring barley is influenced by the presence of a ryegrass catch crop: Results from a lysimeter experiment. Agr iculture, Ecosystems \& Environment 2005; 111: 21-29.

Torbert HA, Prior SA, Rogers $\mathrm{HH}$, Runion GB. Elevated atmospheric $\mathrm{CO}_{2}$ effects on $\mathrm{N}$ fertilization in grain sorghum and soybean. Field Crop Res 2004;88:57-67.

Tuck G, Glendining MJ, Smith P, House JI, Wattenbach M. The potential distribution of bioenergy crops in Europe under present and future climate. Biomass Bioenerg 2006;30:18397.

UKRG. Impacts of nitrogen deposition on terrestrial ecosystems United Kingdom Review Group on Impacts of Atmospheric Nitrogen, DoE, London, 1994.

UKTAG. 2008. UK Environmental Standards and Conditions. UK Technical Advisory Group on the Water Framework Directive. Available from http://www.wfduk.org/UK Environment al Standards/LibraryPublicDocs/UKTAG Report Surface Water Standards and Condition $\underline{\mathrm{S}}$

UKWIR. Implications of changing groundwater quality for water resources and the UK water industry. Phase 3: Financial and water resources impact. UK Water Industry Research, Report Ref. 04/WR/09/08, London, 2004.

Ulen B, Johansson G. Long-term nutrient leaching from a Swedish arable field with intensified crop production against a background of climate change. Acta Agr Scand Section B-S P 2009;59:157-69.

Vachaud G, Chen T. Sensitivity of computed values of water balance and nitrate leaching to within soil class variability of transport parameters. J Hydrol 2002;264:87-100.

van Roosmalen L, Sonnenborg TO, Jensen KH. Impact of climate and land use change on the hydrology of a large-scale agricultural catchment. Water Resour Res 2009; .

Wakida FT, Lerner DN. Non-agricultural sources of groundwater nitrate: a review and case study. Water Res 2005;39:3-16.

Wang L, Stuart ME, Bloomfield JP, Butcher AS, Gooddy DC et al. Regional scale prediction of the arrival of peak nitrate concentrations at the water table: a case study from Great Britain. Accepted by Hydrological Processes.

Watts DG, Martin DL. Effects of water and nitrogen management on nitrate leaching loss from sands. Trans ASAE 1981;24: 0911-6.

Weatherhead EK, Howden NJK. The relationship between land use and surface water resources in the UK. Land Use Policy 2009;26:S243-50.

Wegehenkel M, Kersebaum KC. A first assessment of the impact of climate change on discharge and groundwater recharge in a catchment in Northeastern Germany. International Symposium on Agrometeorology and Food Security, Hyderabad, INDIA, 2008, pp. 274-281. 
Wells RR, DiCarlo DA, Steenhuis TS, Parlange J-Y, Römkens MJM, Prasad SN. Infiltration and surface geometry features of a swelling soil following successive simulated rainstorms. Soil Sci Soc Am J. 2003;67:1344-51.

White RE, Wellings SR, Bell JP. Seasonal variations in nitrate leaching in structured clay soils under mixed land use. Agr Water Manage 1983;7:391-410.

Whitehead PG, Wilby RL, Battarbee RW, Kernan M, Wade AJ. A review of the potential impacts of climate change on surface water quality. Hydrol Sci 2009;54:101-23.

Wilby RL, Orr HG, Hedger M, Forrow D, Blackmore M. Risks posed by climate change to the delivery of Water Framework Directive objectives in the UK. Environ Int 2006;32:104355.

Wilkinson WB, Cooper DM. The response of idealized aquifer/river systems to climate change. Hydrol Sci J 1993;38:379-90.

Wilson GB, Andrews JN, Bath AH. The nitrogen isotope composition of groundwater nitrates from the East Midlands Triassic Sandstone aquifer, England. J Hydrol 1994;157:3546.

Woldeamlak ST, Batelaan O, De Smedt F. Effects of climate change on the groundwater system in the Grote-Nete catchment, Belgium. Hydroge J 2007;15:891-901.

Worrall F, Spencer E, Burt TP. The effectiveness of nitrate vulnerable zones for limiting surface water nitrate concentrations. J Hydrol 2009;370:21-8.

Wright RF, Beier C, Cosby BJ. Effects of nitrogen deposition and climate change on nitrogen runoff at Norwegian boreal forest catchments: the MERLIN model applied to Risdalsheia (RAIN and CLIMEX projects). Hydrol Earth Syst Sci 1998;2: 99-414.

$\mathrm{Wu}$ L, Baker JM, Allmaras RR. Numerical and field evaluation of soil water sampled by suction lysimeters. J Environ Qual 1995;24:147-52.

Younger PL, Teutsch G, Custodio E, Elliot T, Manzano M, Sauter M. Assessments of the sensitivity to climate change of flow and natural water quality in four major carbonate aquifers of Europe. In: Hiscock KM, Rivett MO, Davison RM, editors. Response of Aquifers to Future Climate Change, 2002, pp. 303-23.

Yusoff I, Hiscock KM, Conway D. Simulation of the impacts of climate change on groundwater resources in eastern England. In: Hiscock KM, Rivett MO, Davison RM, editors. Response of Aquifers to Future Climate Change, 2002, pp. 325-44.

Zhao R-F, Chen X-P, Zhang F-S, Zhang H, Schroder J, Romheld V. Fertilization and nitrogen balance in a wheat-maize rotation system in north China. Agron J 2006;98:938-45.

Zhu Y, Fox RH. Corn-soybean rotation effects on nitrate leaching. Agron J 2003;95:1028-33. 
Table 1 . Summary of projected seasonal and annual changes by 2080 using the UKCP09 scenarios

\begin{tabular}{|c|c|c|c|}
\hline Variable & Overall & Area most affected & Area least affected \\
\hline $\begin{array}{l}\text { Mean daily maximum } \\
\text { summer temperatures }\end{array}$ & $\begin{array}{l}\text { Increase } \\
\text { everywhere }\end{array}$ & $\begin{array}{l}\text { Up to } 5.4^{\circ} \mathrm{C}(2.2 \text { to } \\
\left.9.5^{\circ} \mathrm{C}\right) \text { in parts of } \\
\text { southern England }\end{array}$ & $\begin{array}{l}2.8^{\circ} \mathrm{C}\left(1 \text { to } 5^{\circ} \mathrm{C}\right) \text { in parts } \\
\text { of northern Britain. }\end{array}$ \\
\hline $\begin{array}{l}\text { Mean daily minimum } \\
\text { winter temperature }\end{array}$ & $\begin{array}{l}\text { Increase } \\
\text { everywhere }\end{array}$ & \multicolumn{2}{|c|}{$\begin{array}{l}\text { Increases by about } 2.1^{\circ} \mathrm{C}\left(0.6 \text { to } 3.7^{\circ} \mathrm{C}\right) \text { to } 3.5^{\circ} \mathrm{C}(1.5 \text { to } \\
\left.5.9^{\circ} \mathrm{C}\right) \text { across the country }\end{array}$} \\
\hline Annual precipitation & Very little change & \multicolumn{2}{|c|}{$\begin{array}{l}\text { Changes range from }-16 \% \text { to }+14 \% \text { with no clear } \\
\text { geographical pattern. }\end{array}$} \\
\hline Precipitation in winter & Regional variation & $\begin{array}{l}\text { Up to }+33 \%(+9 \text { to } 70 \%) \\
\text { along the western side of } \\
\text { the UK }\end{array}$ & $\begin{array}{l}\text { Small decreases }(-11 \text { to } \\
+7 \%) \text { over parts of the } \\
\text { Scottish highlands. }\end{array}$ \\
\hline $\begin{array}{l}\text { Precipitation in } \\
\text { summer }\end{array}$ & $\begin{array}{l}\text { Decrease for most } \\
\text { places }\end{array}$ & $\begin{array}{l}\text { Up to }-40 \%(-65 \text { to }-6 \%) \\
\text { in parts of the far south of } \\
\text { England. }\end{array}$ & $\begin{array}{l}\text { Little change ( }-8 \text { to } \\
+10 \%) \text { over parts of } \\
\text { northern Scotland. }\end{array}$ \\
\hline
\end{tabular}


Table 2. Possible impacts on European temperate crops (from Bisgrove and Hadley (2002) and Olesen and Bindi (2002))

\begin{tabular}{|c|c|c|c|c|c|}
\hline Crop group & Growth type & Effect of temperature increase & Effect of increased $\mathrm{CO}_{2}$ & Management options & Geographical change \\
\hline $\begin{array}{l}\text { Cereals, } \\
\text { oilseed and } \\
\text { legumes }\end{array}$ & & $\begin{array}{l}\text { Negative- Shorter growing } \\
\text { period and reduced yield }\end{array}$ & $\begin{array}{l}\text { Positive- Increased } \\
\text { growth and increased } \\
\text { nitrogen fixation in pulses }\end{array}$ & $\begin{array}{l}\text { Early planting of spring cereals } \\
\text { Use of longer-season cultivars } \\
\text { later sowing date for winter } \\
\text { cereals }\end{array}$ & $\begin{array}{l}\text { Expansion into the north of cooler } \\
\text { season seed crops (pea, bean, oil seed } \\
\text { rape) and northwards of warmer } \\
\text { season crops (soybean and sunflower) }\end{array}$ \\
\hline \multirow[t]{2}{*}{$\begin{array}{l}\text { Root and } \\
\text { tubers }\end{array}$} & $\begin{array}{l}\text { Determinate e.g. } \\
\text { potatoes }\end{array}$ & $\begin{array}{l}\text { Negative- Reduced growing } \\
\text { season and increased water } \\
\text { requirement and yield variability }\end{array}$ & $\begin{array}{l}\text { Positive- Large increase in } \\
\text { yield }\end{array}$ & $\begin{array}{l}\text { Advanced planting and } \\
\text { cultivation of new varieties }\end{array}$ & \\
\hline & $\begin{array}{l}\text { Indeterminate e.g. } \\
\text { sugar beet }\end{array}$ & $\begin{array}{l}\text { Positive - extension of growing } \\
\text { period }\end{array}$ & $\begin{array}{l}\text { Positive - increase in } \\
\text { yield }\end{array}$ & Requires sufficient water & \\
\hline \multirow[t]{3}{*}{$\begin{array}{l}\text { Horticultural } \\
\text { field and } \\
\text { glasshouse }\end{array}$} & $\begin{array}{l}\text { Determinate e.g. } \\
\text { onion, cauliflower, } \\
\text { broccoli }\end{array}$ & $\begin{array}{l}\text { Negative - Shorter growing } \\
\text { period and reduced yield or } \\
\text { quality }\end{array}$ & & & $\begin{array}{l}\text { Production of field-grown crops } \\
\text { expanding northwards }\end{array}$ \\
\hline & $\begin{array}{l}\text { Indeterminate e.g. } \\
\text { carrots }\end{array}$ & Positive- & & & $\begin{array}{l}\text { Production of field-grown crops } \\
\text { expanding northwards }\end{array}$ \\
\hline & Lettuce & None & Increased yield & & \\
\hline Perennial & $\begin{array}{l}\text { Grapevines, } \\
\text { orchards, soft fruit }\end{array}$ & $\begin{array}{l}\text { Increased yield variability for } \\
\text { grapes. Fruit trees and bushes } \\
\text { may have vernalisation } \\
\text { requirement } \\
\text { Increased growth }\end{array}$ & Increased yields & Substitution of cultivars. & $\begin{array}{l}\text { Expansion of areas north and } \\
\text { eastwards } \\
\text { Change from apples, pears and } \\
\text { cherries to peaches in southern UK }\end{array}$ \\
\hline \multirow[t]{4}{*}{$\begin{array}{l}\text { Forage crops } \\
\text { and grass }\end{array}$} & $\begin{array}{l}\text { Determinate e.g. } \\
\text { whole wheat } \\
\text { Indeterminate e.g. } \\
\text { sugar beet, silage } \\
\text { maize }\end{array}$ & $\begin{array}{l}\text { Increased digestibility but } \\
\text { decreased yield } \\
\text { Increased yield }\end{array}$ & $\begin{array}{l}\text { Increased yield but } \\
\text { decreased digestibility } \\
\text { Increased yield }\end{array}$ & $\begin{array}{l}\text { Change in type to indeterminate } \\
\text { crops } \\
\text { Requires sufficient water }\end{array}$ & $\begin{array}{l}\text { Increase in forage maize in northern } \\
\text { areas }\end{array}$ \\
\hline & $\begin{array}{l}\text { Intensively } \\
\text { managed grass }\end{array}$ & Positive - increased yield & Positive - increased yield & Requires water management & \\
\hline & $\begin{array}{l}\text { N-poor and } \\
\text { species-rich grass }\end{array}$ & Varies depending on species mix & $\begin{array}{l}\text { Little response short-term, } \\
\text { but positive long-term due } \\
\text { to increased fixation }\end{array}$ & $\begin{array}{l}\text { Maintain species richness. } \\
\text { Change cutting height }\end{array}$ & $\begin{array}{l}\text { Area reduced due to expansion of } \\
\text { cropped area }\end{array}$ \\
\hline & Legumes & & $\begin{array}{l}\text { Positive - due to increased } \\
\text { fixation }\end{array}$ & & \\
\hline Livestock & Grazing & & $\begin{array}{l}\text { Increase in milk } \\
\text { production for clover } \\
\text { swards }\end{array}$ & & \\
\hline
\end{tabular}


Table 3 Estimated annual nitrate leaching losses beneath individual crops in northwest Europe and Canada (ADAS, 1991; Gasser et al., 2003; Johnsson et al., 2002; MAFF, 1999)

\begin{tabular}{ll}
\hline Crop & Nitrate leaching $\left(\mathbf{k g ~ N ~ h a} \mathbf{~}^{-1}\right)$ \\
\hline Outdoor vegetables & 120 \\
Potatoes & $80-120$ \\
Oilseed rape & $65-100$ \\
Peas \& beans & $60-80$ \\
Sugar beet & $45-60$ \\
Indoor vegetables and flowers & 60 \\
Barley & $35-50$ \\
Oats & 48 \\
Wheat & $40-50$ \\
Grazed grass $\left(250 \mathrm{kgN} \mathrm{ha}^{-1}\right.$ applied $)$ & 40 \\
Cut grass $\left(250 \mathrm{kgN} \mathrm{ha}^{-1}\right.$ applied) & 20 \\
Ungrazed or fertilised grass & 10 \\
\hline
\end{tabular}


Table 4. Climate change impacts on crop yield, distribution, leaching process and nonagricultural nitrogen sources

\begin{tabular}{|c|c|c|}
\hline \multirow[t]{2}{*}{ Factor } & \multicolumn{2}{|c|}{ Scale of changes } \\
\hline & Short term- 2020 & Longer term- 2050 \\
\hline \multicolumn{3}{|l|}{ Changes in crop yield and distribution } \\
\hline \multirow[t]{2}{*}{ Increased temperature } & Increased yield & Decreased yield \\
\hline & $\begin{array}{c}\text { Northwards extension } \\
\text { within UK }\end{array}$ & $\begin{array}{l}\text { Decline in southern } \\
\text { parts of UK }\end{array}$ \\
\hline Decreased summer recharge & Decreased yield & Decreased yield \\
\hline Increased variability of recharge \& extreme events & Decreased yield & Decreased yield \\
\hline Increased atmospheric $\mathrm{CO}_{2}$ & Yield increase & $30 \%$ yield increase \\
\hline New crops & \multicolumn{2}{|c|}{ Northwards extension within UK } \\
\hline Pests & Increase & Increase \\
\hline \multicolumn{3}{|l|}{ Impact of climate change on leaching processes } \\
\hline Increased temperature & Increase $2 \mathrm{~kg} \mathrm{ha}^{-1} \mathrm{yr}^{-1}$ & Increase \\
\hline Increased winter soil moisture & \multicolumn{2}{|c|}{ Increase } \\
\hline Decreased summer soil moisture & \multicolumn{2}{|c|}{ Decrease } \\
\hline Increased leaching due to storm events & \multicolumn{2}{|c|}{ Increase } \\
\hline New crops & \multicolumn{2}{|c|}{$?$} \\
\hline \multicolumn{3}{|l|}{ Other sources } \\
\hline Nitrogen deposition & \multicolumn{2}{|c|}{ Small change } \\
\hline Urban areas & Not known & Small change \\
\hline
\end{tabular}


Table 5. Projected impacts of climate change on recharge and water resources for other areas

\begin{tabular}{|c|c|c|c|c|}
\hline Area & Assumptions & Model & Projected result & Reference \\
\hline Ireland & $\begin{array}{l}\text { HadCM2 } \\
\text { Recharge held constant }\end{array}$ & HYSIM & $\begin{array}{l}\text { Overall decrease in effective run-off with increase in winter } \\
\text { and larger decrease in summer. }\end{array}$ & Charlton et al. (2001) \\
\hline $\begin{array}{l}\text { Seine Basin, } \\
\text { France }\end{array}$ & SRES-A2 scenario & $\begin{array}{l}\text { CLSM, } \\
\text { MODCOU, } \\
\text { STICS }\end{array}$ & $\begin{array}{l}\text { Enhanced seasonal contrast in water levels. } 10 \% \text { increase in } \\
\text { PET. }\end{array}$ & Ducharne et al. (2007) \\
\hline $\begin{array}{l}\text { Hesbaye } \\
\text { aquifer, Geer }\end{array}$ & $\begin{array}{l}\text { HadCM2, ECHAM4 and } \\
\text { CGCM1 scenarios }\end{array}$ & MOHISE & Decrease in groundwater levels and reserves. & Brouyère et al.(2004) \\
\hline $\begin{array}{l}\text { Basin, } \\
\text { Belgium }\end{array}$ & $\begin{array}{l}\text { PRUDENCE RCM, SRES- } \\
\text { A2 scenarios }\end{array}$ & HydroGeoSphere & $\begin{array}{l}\text { Decrease in annual precipitation with warmer wetter winters } \\
\text { and much hotter drier summers. Increased frequency of } \\
\text { summer droughts and significant reductions in groundwater } \\
\text { levels by } 2041 \text { with larger decreases by } 2070 \text {. }\end{array}$ & Goderniaux et al.(2009) \\
\hline $\begin{array}{l}\text { Grote-Nete, } \\
\text { Belgium }\end{array}$ & NATCC, wet cold and dry & $\begin{array}{l}\text { Wetspass, } \\
\text { ModFlow }\end{array}$ & $\begin{array}{l}\text { Groundwater level increase by up to } 0.8 \mathrm{~m} \text { for wet high } \\
\text { temperature scenario, but decrease by } 0.5 \mathrm{~m} \text { for dry scenario. }\end{array}$ & Woldeamlak et al. (2007) \\
\hline $\begin{array}{l}\text { Ucker } \\
\text { catchment, NE } \\
\text { Germany }\end{array}$ & $\begin{array}{l}\text { PICIR, variants of the A1B } \\
\text { scenario }\end{array}$ & & Groundwater recharge decrease by an order of magnitude & $\begin{array}{l}\text { Wegehenkel and } \\
\text { Kersebaum (2008) }\end{array}$ \\
\hline $\begin{array}{l}\text { Southeast } \\
\text { Spain karst }\end{array}$ & Actual over last century & ERAS & $\begin{array}{l}\text { Simulated observed decreases in effective precipitation and } \\
\text { groundwater recharge. }\end{array}$ & $\begin{array}{l}\text { Aguilera and Murillo } \\
(2009)\end{array}$ \\
\hline $\begin{array}{l}\text { Northern } \\
\text { Portugal. }\end{array}$ & & Various & $\begin{array}{l}\text { Decrease in recharge of } 70 \% \text { for a } 30 \% \text { reduction in actual } \\
\text { recharge. }\end{array}$ & Oliveira et al (2005) \\
\hline Denmark & SRES-A2 and B2 scenarios & & $\begin{array}{l}\text { Annual recharge increased significantly (especially under the } \\
\text { B2) giving higher groundwater heads. }\end{array}$ & $\begin{array}{l}\text { Van Roosmalen et al. } \\
(2009)\end{array}$ \\
\hline $\begin{array}{l}\text { Grand Forks, } \\
\text { Canada }\end{array}$ & CGCM1 scenarios & HELP & $\begin{array}{l}\text { Increased winter and spring recharge (affected by } \\
\text { considerable winter snow cover). }\end{array}$ & $\begin{array}{l}\text { Scibek and Allen (2006), } \\
\text { Scibek et al. (2007) }\end{array}$ \\
\hline $\begin{array}{l}\text { Great Plains, } \\
\text { Oklahoma, } \\
\text { USA }\end{array}$ & $\begin{array}{l}3 \text { scenarios using } 1999 \\
\text { climate values }\end{array}$ & & $\begin{array}{l}\text { Where the water table is shallow changes are primarily a } \\
\text { function of temperature increase and for deeper water tables a } \\
\text { function of precipitation. }\end{array}$ & $\begin{array}{l}\text { Maxwell and Kollet } \\
(2008)\end{array}$ \\
\hline
\end{tabular}

CGCM1 - Canadian Centre for Climate Modelling and Analysis. ECHAM4- German Climate Research Centre, NATCC - North Atlantic Thermohaline Circulation Change, PICIR-Potsdam Institute of Climate Impact Research 
Table 6 Environmental responses to climate policy (from Baker and Murray, 2009)

\begin{tabular}{lllll}
\hline Climate policy scope & \multicolumn{2}{c}{ Groundwater extraction } & \multicolumn{2}{c}{ Nitrate leaching } \\
& Decrease & Increase & Decrease & Increase \\
\hline $\begin{array}{l}\text { Bioenergy only } \\
\text { Bioenergy and } \mathrm{CO}_{2} \text { only }\end{array}$ & $\begin{array}{l}\text { No } \\
\text { If cost effect } \\
\text { dominates }\end{array}$ & $\begin{array}{l}\text { Yes } \\
\text { If price effect } \\
\text { dominates }\end{array}$ & No & Yes \\
$\begin{array}{l}\text { Bioenergy and greenhouse } \\
\text { gases except } \mathrm{CO}_{2}\end{array}$ & No & Yes & Yes & No \\
$\begin{array}{l}\text { Bioenergy and all greenhouse } \\
\text { gases }\end{array}$ & $\begin{array}{l}\text { If cost effect } \\
\text { dominates }\end{array}$ & $\begin{array}{l}\text { If price effect } \\
\text { dominates }\end{array}$ & $\begin{array}{l}\text { If cost effect } \\
\text { dominates }\end{array}$ & $\begin{array}{l}\text { If price effect } \\
\text { dominates }\end{array}$ \\
\hline
\end{tabular}




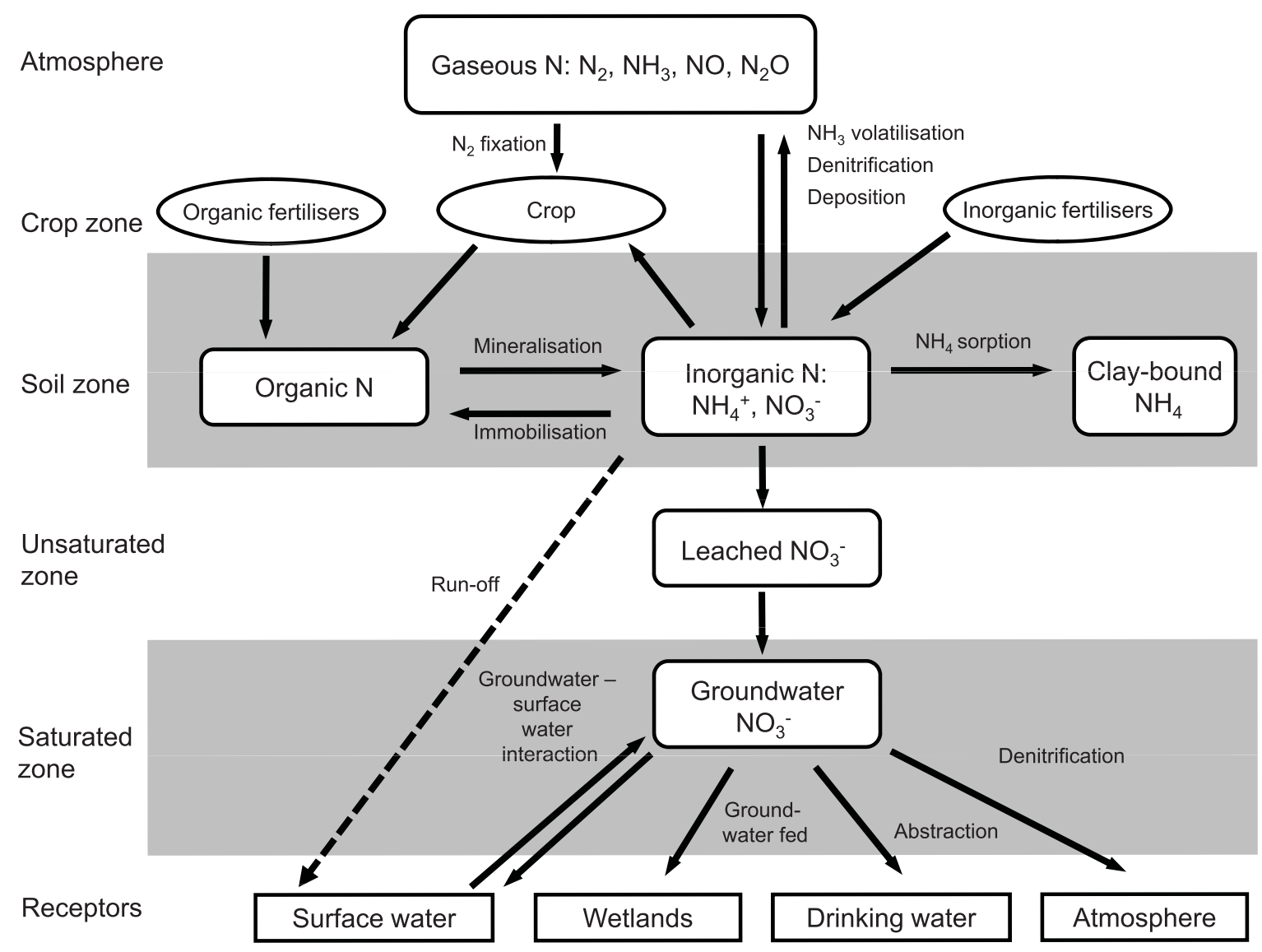

Fig. 1. Simplified nitrogen cycle highlighting soil processes 


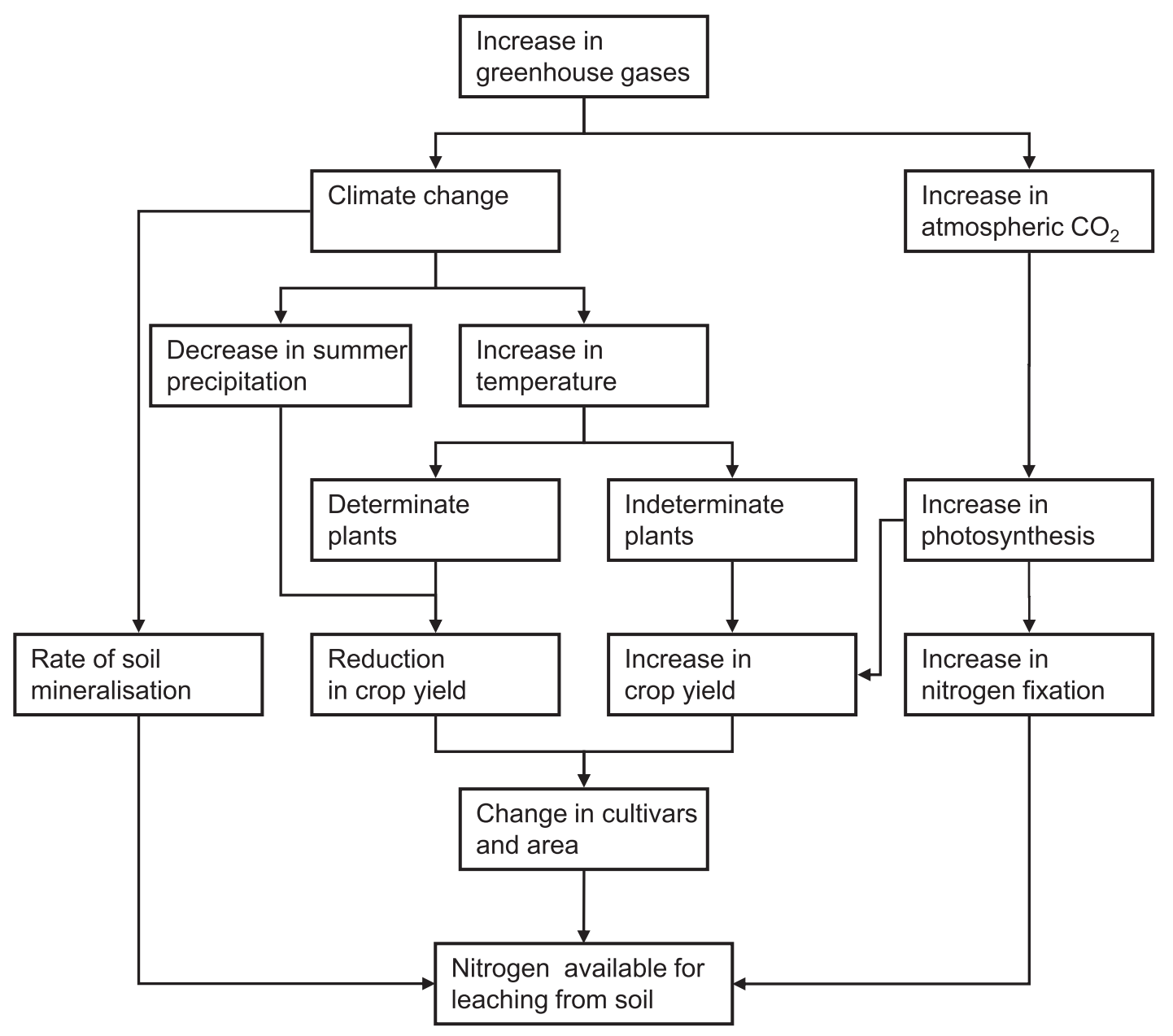

Fig. 2. Interrelationship of impacts of climate change on soil nitrate available for leaching from agricultural areas 


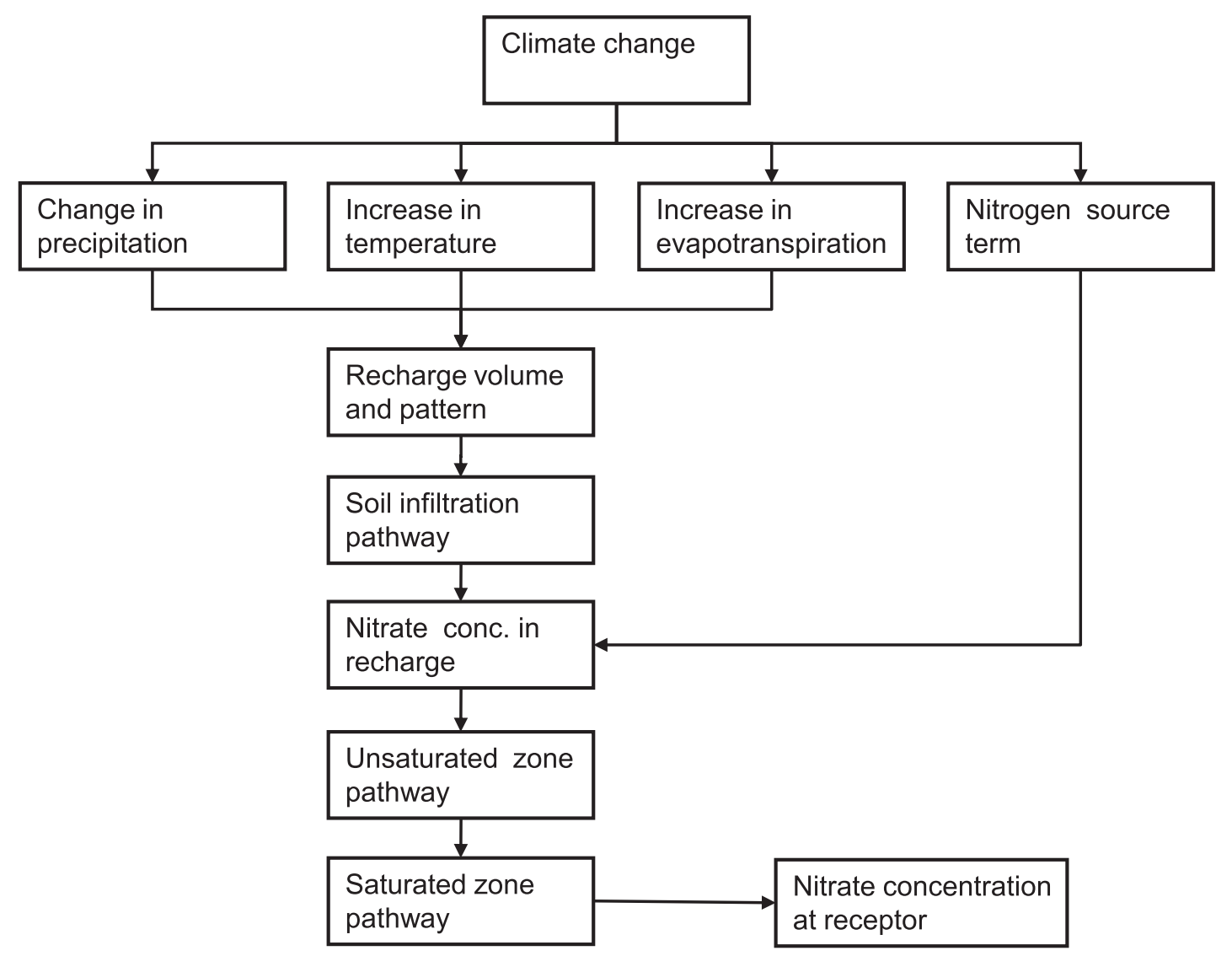

Fig. 3. Routes for climate change impact on nitrate leaching pathways 